\section{Core elements, crime prevention policies and limitations of Agnew's general theory of crime and delinquency}

\section{Ahmet Eker ${ }^{1}$}

\begin{abstract}
Agnew has integrated and re-organized several leading criminological theories and results of empirical researches arguing that this new general theory has the capability of explaining all crime types. Effects of five life domains (self, family, peer, school and work) on individuals' behaviors and decision making process have been explained in this theory. These five life domains encompass and affect whole lifespan of a person starting from the early childhood. These life domains not only affect individuals but also have mutual effect on each other. In addition, several external factors have effects on individuals, and in order to commit crimes, these external factors should interact with other variables (biological factors, family, school, etc.). If these life domains and other external factors have negative effects on individuals, the probability of offending will increase. On the other hand, if they provide positive support, their effects will protect individuals from engaging in crime. Additionally, this theory tries to explain the reasons why some individuals engage in criminal behaviors while others do not even though they share the same environments. Prior crime has been found one of the strongest factors that cause subsequent crimes. The core elements, variables that cause crime, crime prevention policies, and limitations of this theory are analyzed in this paper.
\end{abstract}

\section{Agnew'in suç ve çocuk suçluluğu genel teorisinin temel unsurları, suç önleme politikaları ve limitleri}

\section{Özet}

Agnew birçok önemli teoriyi ve bilimsel çalışmaların sonuçlarını birleştirerek ve yeniden organize ederek tüm suçlar1 açıkladığını iddia ettiği kapsamlı bir genel suç teorisi yazmıştır. Bu teoride suça doğruca etki eden beş farklı yaşam alanının (bireyin kendisi, aile, arkadaş, okul ve iş) bireyin karar verme sürecine ve davranışlarına olan etkileri anlatılmıştır. Bu beş yaşam alanı bireylerin çocukluk yıllarından başlayarak tüm yaşantısını kaplamakta ve etkilemektedir. Yaşam alanları sadece bireyi etkilememekte ayn zamanda birbirlerini de etkilemektedirler. Bunlara ilaveten, diğger harici birçok faktörün bireyler üzerinde etkili olduğunu ve suçun oluşabilmesi için bu faktörlerin diğer faktörler ile (biyolojik faktörler, aile, okul, vb.) beraber mevcut olması ve etkileşime geçmesi gerektiği iddia edilmiştir. Bu yaşam alanları ve diğer faktörler bireye negatif etki yaptıklarında suç işleme ihtimalinin artacağı, öte yandan pozitif destek sağllyorlarsa suçtan koruyucu etki yapacakları belirtilmiştir. Ayrıca, aynı koşullarda yaşayan bireylerin suç işleme veya işlememe konusunda sergiledikleri farklı davranışların sebepleri anlatılmıştır. Önceki suçların daha sonra suç işlemeye çok büyük etkisinin olduğu bulunmuştur. Bu makalede bu teorinin temel argümanları, suça neden olan faktörler, suç önleme önerileri ve bu teoriye getirilen 
Eker, A. (2016). Agnew'in suç ve çocuk suçluluğu genel teorisinin temel unsurları, suç önleme politikaları ve limitleri. International Journal of Human Sciences, 13(1), 1945-1968. doi:10.14687/ijhs.v13i1.3735

Keywords: Strain; Delinquency; Life Domain; Interaction; Protective Factors; Rehabilitation; Family; School; Delinquent Peers; Work; Social Control; Self-Control; Social Learning; Social Support.

(Extended English abstract is at the end of this document) eleştiriler incelenmiştir.

Anahtar Kelimeler: Gerilim; Suç; Çocuk Suçluluğu; Yaşam Alanı; Etkileşim; Suçtan Koruyucu Faktörler; Tedavi; Aile; Okul; Suçlu Arkadaş; İş; Sosyal Kontrol; Öz-Kontrol; Sosyal Öğrenme; Sosyal Destek.

\section{Giriş}

Agnew insanların birçoğunun suçlu kişileri du davranışları işlemeye iten temel nedenleri öğrenmek istediğini ancak teorisyenlerin farklı cevaplar verdiklerini belirtmektedir. Örneğin, bazı teorisyenler risk faktörlerini sıralamakta ve "sinirlilik-tez canlllik, ailevi sorunlar, suçlu arkadaş çevresi ve çete mensubu olma" gibi faktörlerin bireyleri suça ittiğini iddia etmektedirler. Diğer bazı teorisyenler ise birçok önde gelen teorileri birleştirmekte ve ortaya çıkardıkları yeni birleşik teoriyi kullanarak kişilerin neden suç işlediklerini izah etmeye çalısmaktadırlar. Ancak, Agnew yapılan bu açıklamaların kendisini tatmin etmediğini ve bu temel soruya kapsamlı ve tatmin edici bir cevabın verilemediğini belirtmektedir. Agnew, bu soruya kapsamlı bir cevap verebilecek şümullü bir teorinin suça iten temel nedenlerin neler olduğunu ve bu nedenlerin niçin ve nasul suça ittiğini, birbirlerinden farkl olan bu nedenlerin birbirleri ile olan iliskilerini ve etkilesimlerini, önceki suclarn neden ve nasil sonraki suclar etkilediğini ve en önemlisi bu faktörlere maruz, kalan bazı bireyler suç işlerken neden diğerlerinin suc ișlemediğini izah etmesi gerektiğini iddia etmektedir (2005:2-4).

25 yıllık tecrübeli ve etkili bir teorisyen ve araştırmacı olan Agnew'e göre yukarıdaki soruların içerisindeki en önemli ve kapsaml soru "baž bireylerin diğerlerine göre suç işleme olasillğgmm neden daha faそla olduğu" sorusudur (2005: 1-2). Başka bir ifade ile Agnew'in bu teorisi "suçu davranıslar toplum tarafindan kinanmakta iken ve yakalanuldığnda hapse girme ibtimali çok yü̈ksek iken neden bą? kişiler diğerlerine göre daha fazla suc işlerler?" sorusuna odaklanmaktadır. Buna ilaveten, "yetersiz, ebeveyn ve suclu çevre-arkadaş gibi birçok olumsuz̆luğa maruz kalmalarna rağmen neden baz̧ kişiler suc işlememektedirler?" sorusuna cevap olacak şekilde yazılmıştur (2005: 12).

"Entegre biyolojik-sosyal kriminolojik" yaklaşımı benimseyen (Walsh, 2005: 87) bu teoriyi diğer teorilerden farklı ve bir yönüyle avantajlı yapan en güçlü tarafı "önde gelen suç teorilerini ve suç üzerine yapılmış olan bilimsel araştırmaları bu kapsamlı teorisinde organize etmesidir (Zhang, Day, \& Cao., 2012: 857). Bu yaklaşımın sonucu olarak bilimsel yönü güçlü olan, bireylerin davranışlarına ve sonuçlarına kapsayıcı açıklamalar getiren ve bu iddiaları birçok akdemisyen tarafindan test edilen ve desteklenen Agnew'in bu çok meşhur olan teorisinin açıklamaları "sadece kriminoloji alanında değil "yeme bozukluğu" gibi diğer olayları izah etmekte" de kullanılmaktadır (Froggio, 2007: 384). Birçok teoriyi birleştiren Agnew’e göre bir kişinin suç işlemesinin üç temel nedeni vardır: "(1) bu kişilerin yaşadıkları çevrede başkaları tarafından kınanma ve ceza alma riski düşüktür; (2) bu kişiler kınanma ve cezalardan az kaygı duymalarına neden olan kişisel özellikler geliştirmişlerdir; (3) bu bireyler suç işlemek için çok güçlü bir içgüdüye ve motivasyona sahiptirler" (2005: 13). Bu üç madde çok kısa olmakla beraber içerikleri derinlemesine analiz edildiğinde aslında Agnew’in birçok teoriden süzdüğü genel ve geçerli hipotezler oldukları görülecektir. Örneğin, birinci maddede ayrıştırıcı birliktelikler teorisini, ikinci maddede Sykes ve Matza'nın nötürleme tekniklerini ve son maddede gerilim teorilerini görmek mümkündür.

$\mathrm{Bu}$ yeni teorisin suç ve çocuk suçluluğunu tüm yönleri ile açıklayabilecek kapsamlı bir teori olduğunu iddia eden Agnew, teorisini yukarıdaki üç temel nedenin sebeplerini ve nasıl geliştiklerini izah edecek şekilde tasarlamıştır. Bu teorisinde "suça neden olan birçok faktörü listelemek ya da bir faktör ile sınırlı kalarak onu derinlemesine inceleme gibi aşırı uç yöntemler yerine orta bir yol tutmuş ve suça direk etkisi olan benzer faktörleri gruplayarak suçun nedenlerini” izah etmeye çalışmıştır. Yazarın kendisinin de iddia ettiği gibi bu yöntemi kullanmak bu teoriyi anlaşıllır ve düzenli yapmıştır. 
Eker, A. (2016). Agnew'in suç ve çocuk suçluluğu genel teorisinin temel unsurları, suç önleme politikaları ve limitleri. International Journal of Human Sciences, 13(1), 1945-1968. doi:10.14687/ijhs.v13i1.3735

Agnew'e göre bireyleri suça iten veya suçtan koruyan beş ana yaşam alanı vardır: bireyin kendi özellikleri, aile, okul, arkadaş grubu ve iş kalitesi/iş ortamı. Agnew'in bu şümullü teorisi temel olarak "bu grupların her birisinin neden ve nasil suça sebep olduğunu ve birbirleri ile olan etkileşimlerini" ve bu etkileşimlerden meydana gelen "ortak etkinin" suç işlemeye "nasıl" motive ettiğini izah etmektedir (2005: 10-11). Agnew bu ana faktörlere ilaveten birçok harici faktörün (biyolojik özellikler, sosyoekonomik yapı, cinsiyet, vb.) ana faktörler ile etkileşime geçerek bireyin davranışlarını etkilediğini iddia etmektedir. Ayrıca, rutin aktiviteler teorisinin açıklamalarından faydalanarak bir bireyin illegal faaliyetini gerçekleştirebilmesi için "suç işleme imkânının/ortamının" olması gerektiğini ve illegal davranış sergileyecek her bir bireyin "suçun nasıl işleneceğini bilmesinin" şart olduğunu ve suç işlemeye yetecek derecede "bireysel becerisinin, fiziksel ve zihinsel kapasitesinin" olmas1 gerektiğini belirtmektedir (2005: 30). Bu paragrafta Agnew'in genel teorisi ana hatları ile özetlenmiştir. Bu özet iki noktayı göstermektedir. Birinci olarak bu teori gerçekten çok kapsamlıdır ve suça etki etmeye çalışan tüm faktörleri bir araya getirmeye çalışmıştır. İkinci olarak, Agnew bu teorisinin ortasına beş yaşam alanını yerleştirmiş ve teorisini bu alanların etrafında organize ederek teorisini karmaşık ve zor anlaşlır bir teori olmaktan kurtarmıştır.

Agnew bu teorisini geliştirirken birçok suç teorisinden ve bilimsel çalışmalardan faydalanmıştır. Suç teorilerinde ve bilimsel çalışmaların sonucunda bireye olumlu veya olumsuz etkisi ispat edilen faktörleri de teorisine dâhil etmiştir. Agnew sadece faktörleri sıralamamış daha da önemlisi onları özelliklerine göre gruplandırmıştır. Daha da önemlisi bu faktörlerin sadece bireye olan etkisine değil birbirlerine olan etkilerine de bakmışur (Agnew, 2005). Agnew'in bu yaklaşımının Türkiye'de işlenmekte olan suçların nedenlerini anlamada araşturmacılara, kolluk güçlerine ve tedavi programları uygulayan uzmanlara kapsamlı bir bakış açısı getireceğinde hiç kuşku yoktur. Bunlara ilaveten, Türkiye'deki literatür taraması sonucundaTürk akademisyenlerin büyük çoğunluğunun Agnew'in 1992 yllında yazmış olduğu ve daha sonraki yıllarda geliştirdiği "Genel Gerilim Teorisini" kullandıkları görülmektedir. Önceki argümanları da bünyesinde barındıran bu yeni genel teorinin Türkçe olarak literatüre kazandırılmasının yapılacak olan akademik çalışmalara ve suç önleme yöntemlerine katkısı olacağı değerlendirilmektedir. Bu nedenle, Agnew'in genel suç ve çocuk suçluluğu teorisi ve bu teoride bütünleştirilen faktörleri analiz eden bilimsel çalışmaların sonuçları ayrıntılı olarak aşağıda sunulacaktır.

\section{Suçtan Koruyucu ve Suç İşleme Motivasyonunu Artıran Faktörler}

Ek-2'de sunulan tabloda çok ayrıntlli bir şekilde gösterildiği gibi, her bir faktör grubunun genel olarak iki sonucu olmaktadır: "risk faktörleri ve koruyucu faktörler". Risk faktörleri suça iten nedenler iken koruyucu faktörler risk faktörlerinin etkisini azaltarak bireyin suç işleme olasıllı̆ını düşüren faktörlerdir. Koruyucu faktörler üç tanedir: (1) "Dış faktörler (polis, mahkeme, anne-babaarkadaş-işveren-öğretmenler ve komşulardan utanma). (2) İçsel (Öz) kontrol (bireyin kanunları ve kuralları içselleştirmesi, suç işlemeyi ahlaken yanlış bulması ve yüksek öz-kontrol) ve (3) Kurallara uyma ile elde edilecek ödül (iyi bir iş, ünvan, eş, çocuklar ve seçkin sosyal çevre)" (2005:19-21). Bireyleri suça iten risk faktörleri ise beş tanedir: "(1) Sosyal çevrede suçun gözlemlenmesi/öğrenilmesi ve/veya teşvik (arkadaş, anne-baba, akraba ve yakın çevrede yaşayanlar). (2) İşlenen suçtan fayda görmek (para, şöhret, vb.). (3) Başarılı ve sayg1 duyulan suçlu modeller ile beraber olmak. (4) Suçu normalleştirmek ve mazur göstermek (mağdur zarara layıktı, kavga edilebilir, vb.). (5) Suçu öğrenmedeki kişisel yetenek" (2005: 22-25). Agnew "suçtan koruyan faktörlerin etkisinin suça iten etkenlerden daha az olması durumunda bireylerin suç işleme olasılıklarının çok yüksek olacağını" belirtmektedir (2005:31). Agnew'in bu görüşünü destekleyen Elijah Anderson bazı kişilerin bu olumsuz faktörlere maruz kalmalarının daha fazla ve sürekli olacağını ve bu nedenle de bu kişilerin suç işleme olasılıklarının çok daha fazla olduğunu belirtmektedir. Anderson bu durumu "sokak odaklı" bireyler olarak tarif etmekte ve bu kişilerin sokaktaki genel olumsuz davranışlardan etkilenerek sokağın gereğini yerine getirdiklerini belirtmektedir (Agnew, 2005:25). 
Eker, A. (2016). Agnew'in suç ve çocuk suçluluğu genel teorisinin temel unsurları, suç önleme politikalar1 ve limitleri. International Journal of Human Sciences, 13(1), 1945-1968. doi:10.14687/ijhs.v13i1.3735

Agnew suçtan koruyucu ve suça teşvik edici faktörlerin "bireylerin davranışlarını o kişiler hiç farkına varmadan şekillendirdiğini” iddia etmektedir. Daha da önemlisi, kişilerin sıklıkla maruz kaldıkları ve karşılaştıkları bu faktörler bireyin bilinçaltını etkileyerek "bizzat karar verme sürecinin kendisini" şekillendirecek ve "suç işleme ihtimali ile karşılaşıldığında hangi faktörlerin daha etkin olacağına (suçtan koruyucu veya suça itici) ve nasıl değerlendirileceğine bireylerin çoğunlukla bilinçli müdahalesi olmadan" -daha doğru bir ifade ile olamadan- etki edecektir. Agnew'in bu teorisi rasyonel seçim teorisi ile çelişmektedir. Agnew bu açıklaması ile bireylerin tüm davranışlarının bilinçli olmadığını ve önceden şekillenen davranış kalıpları ile tepki vereceğini iddia etmektedir. Agnew yapılan araştırmaların bu görüşünü desteklediğini ve suçtan elde edilen fayda ile cezaların bireyler farkına varmadan bilinçaltlarından onların davranışlarını etkilediğini iddia etmektedir (2005: 32). Agnew'in teorisini destekleyen Zhang, Day, \& Cao lise öğrencileri üzerine gerçekleştirmiş oldukları geniş çaplı araştırmalarının sonucunda gençlerin "suça iten nedenler ve suçtan koruyan faktörlere" maruz kalmaları ile "genç suçluluğu arasında güçlü bir bağ" bulmuşlardır. Bu bağın da ötesinde "suça iten nedenler ve suçtan koruyan faktörlerin genç suçluluğuna önemli oranda direkt ve endirekt etki ettiğini”" ve gençlerin inanış ve davranışlarını şekillendirdiklerini bulmuşlardır (2012: 874).

Sankır (2014) Türkiye'de yapmış olduğu çalışmasında 570 lise öğrencisinin (320 kız, 250 erkek) "benlik saygısı" seviyesini incelemiş ve Agnew'in yukarıdaki iddalarını destekleyen sonuçlara ulaşmıştır. Bu çalş̧maya göre kendisine saygısı yüksek olan gençler suç veya diğer sampa davranışlarını işlemeye daha dirençli bulunmuşlardır. Bunun aksine düşük öz saygısı olan gençlerin illegal davranışlara karşı yeterli dirençlerinin olmadığını, bunun da ötesinde düşük az saygının suç işlemeyi ve sampa davranışlarını gerçekleştirmede katalizör görevi görerek bireyleri olumsuz davranışlara motive etiğini bulmuştur. Türkiye'nin kuzey bölgesindeki bir ilde yapılan bu çalışmanın Agnew'in argümanlarını tamamen desteklemesi bu teorinin diğer ülkelerdeki suçlu davranışları açıklamakta yeterli olduğunu göstermektedir.

Fakat bu noktada Agnew çok önemli bir uyarıda bulunmakta ve bu faktörlerin "suça kesin olarak iteceğini veya suçtan koruyacağını iddia etmediğini ve bu nedenle de "olasılık" kelimesini bilinçli olarak seçtiğini" belirtmektedir. Bireylerin davranışlarını şekillendiren her iki faktörün de "cebrilik" (determinism) dayatmayacağını ve bireylerin her zaman "özgür iradeleri ile seçim yapacaklarını", ancak bu faktörlerin "bireylerin özgür iradelerini çok önemli oranda etkileyeceğini”" iddia etmektedir (2005: 33). Agnew’in bu açıklaması gerçekten çok önemlidir çünkü tüm bilimsel çalışmaların kabul ettiği gibi insan çok karmaşık bir karar verme süreci sergilemektedir. Bir faktörün veya faktörler grubunun cebri olarak suça iteceğini iddia etmek inandırıcılıktan çok uzaktır. Agnew bu hataya düşmemiş ve faktörlerin etkileme güçleri fazla olmakla birlikte cebri değillerdir sonucuna ulaşmışur.

Gerilim teorisyenleri de benzer iddiada bulunmakta ve bireylerin davranışlanını ve karar verme süreçlerini etkileyen en önemli faktörün bu kişilerin yaşadıkları olumsuz olaylar neticesinde ortaya çıkan "gerilim" olduğunu belirtmektedirler. Bu gerilim neticesinde "kızgınlık ve hayal kırıklı̆̆ı" gibi birçok negatif duygu oluşmakta ve bu duygular kişileri, özellikle de yasal yollardan bu kızgınlıklarını giderme imkânı kısıtlı olanları suça motive etmektedir (Merton, 2003; Cohen, 2003). Agnew bu olumsuz olaylara örnek olarak "sözle veya fiziksel olarak şiddet görmek, hedeflere ulaşmanın engellenmesi, değer verilen bir varlığının zorla alınması, şiddet içeren disipline maruz kalma, okulda yaşanan her türlü olumsuzluklar, işsizlik veya düzenli/kalıcı bir iş sahibi olamama, suç mağduru olma ve ayrımcllı̆̆a uğramayı (inanç, politik görüş veya ırkından dolayı)" vermektedir. Agnew bu gerilim kaynaklarının "her birisinin bireyler tarafindan çok önemsendiğini ve adaletsizliğin timsali olarak görüldüğünü, düşük öz-kontrol ve harici kontrol yokluğu ile birleşince kaybedecek çok şeyi olmayan bireyler için suça motive edeci güçlü birer faktör haline geldiklerini” iddia etmektedir (2005:26-27). Agnew bu iddialarını yapılandırırken gerilim teorilerinin argümanlarını kendi teorisine çok mükemmel bir şekilde entegre etmiş ve yaşanılan olumsuzlukların bireyleri suç işlemeye ittiğini belirtmiştir. 
Eker, A. (2016). Agnew'in suç ve çocuk suçluluğu genel teorisinin temel unsurları, suç önleme politikaları ve limitleri. International Journal of Human Sciences, 13(1), 1945-1968. doi:10.14687/ijhs.v13i1.3735

\section{Yaşam Alani}

Yukarıda izah edildiği gibi suçlu davranışlarını açıklamaya çalışan teorisyenler bireyleri suçtan alıkoyan birçok faktörü (içsel, harici ve sosyal birikim) ve suça motive eden onlarca etkeni sıralamaktadırlar (suçun gözlemlenmesi, suçtan fayda görmek, suçlu modeller, suçu normalleştirmek, kişisel yetenek, vb.). Ancak, Agnew "suça direk ve endirekt etki eden tüm etkenlerin listelenmesi yaklaşımının kriminoloji teorilerini çok karmaşık ve anlaşılmaz yaptığını" iddia etmektedir. Bu nedenle Agnew, "suça direkt etki eden ve suçtan koruyan faktörleri beş ana grupta toplamıss ve daha sonra her bir grubun içerisinde yer alan ve benzer etkilere neden olacak alt etkenleri' sıralamıştır. Agnew çok iddialı bir yaklaşım sergileyerek bu beş yaşam grubunun 'bir bireyin hayatmm tüm alanlarm içerdiğini ve suça direkt etki eden tüm etkenleri kapsadiğgn’" iddia etmektedir. Bu beș yaşam alanına dâhil olmayan ancak "bilimsel çalışmalar tarafindan suça etkisi ispat edilen biyolojik eksiklikler, sosyo-ekonomik durum, cinsiyet, yaş, sosyal çevre gibi diğer etkenlerin bu beş alanda belirtilen etkenler üzerinden suça etkilerinin olduğunu" iddia etmektedir (2005: 40). Aşağıda Agnew'in organize etmiş olduğu beş yaşam alanı ve bunların suça nasıl etki ettikleri izah edilecektir.

a- Süper kişilik özelliğ́: Araştırmacı ve teorisyenler suça en fazla ve doğruca etkisi olan özelliğin bireysel özellikler olduğunu bulmuşlardır çünkü bu özellikler kişinin "ne şekilde düşüneceğini, hissedeceğini ve davranacağını" belirlemektedirler” (Agnew, 2005:42). Birçok teoriden faydalanan Agnew bu kişisel özellikleri iki ana grup altında toplamaktadır: "düşük özkontrol” ve "sinirlilik/asabilik". Bu iki grup "süper-kişisel öz̧ellikler?" meydana getirmektedir. Düşük öz-kontrol sahibi olan bireyler "çabucak sinirlenen, risk alan, macera içeren aktiviteleri seven, olumlu şeylere arzu ve motivasyonu düşük olan, ceza ve kınanmayı önemsemeyen, gerilim yaşadığında sorununu suç işleyerek çözmeye meyilli olan, okul ve çalışmadan kısa sürede sıkılan" kişilerdir. Sinirli bireyler ise "çok fazla olumsuz olayla karşılaşmaya meyilli ve bu durumlar nedeni ile karşıdakileri suçlayan, duygu yoğunluğu çok fazla olan ancak karşıdakilerin duygularını önemsemeyen, ceza ve kınanmaya aldırmayan ve sorunlarını en kısa sürede şiddet ile çözmeye" meyilli kişilerdir. Bu özellikler "suçtan koruyan faktörleri azaltırken suç işleme motivasyonu artırmaktadır" (Agnew, 2005:42-44). Agnew'in bu iddiaları ile örtüşen açıklamalar yapan psikiyatri uzmanları psikopatların altı özelliği olduğunu belirtmektedirler. Bu özeliklerden birisi de "çabuk sinirlenme, tez canll1ık ve ileriyi düşünmeden hareket etmedir" (Vold, Bernard, \&Snipes, 2002: 72). Sinirli olan ve kendisini kontrol edemeyen bireylerin karşılaştıkları olumsuzlukları genel olarak şiddet ile çözdüklerini anlatan bu tanımlama Agnew'in iddiasını doğrulamaktadır.

b-Aile (Yetersiz Ebeveynlik ve Evlenmeme/Kötü Evlilik: Çocukların karakterleri annebaba davranışları ile şekillenmektedir. Çocuklar ile anne-babaları arasındaki "bağlar zayıfsa, beraber olumlu aktivitelere katılmaları az ise, aile bireyleri birbirlerinden nefret ediyorlarsa, çocuklara uygulanan disiplin çok gevşek, tutarsız ve şiddet (dayak, bağırma, tehdit) içeriyorsa, çocukların gözetim ve kontrolü yeterli değilse, anne-baba ve aile bireyleri sürekli kavga halinde ve birbirlerine bağıriyor veya dövüyor ise, anne-babadan birisi veya her ikisi de suç işliyor ise bu tür ortamlarda yetişen çocukların suç işleme motivasyonları yüksek olacaktır” (Agnew, 2005:45-47). Agnew bu teorisinin birçok noktasında anne-baba davranışının suça olan etkisine değinmekte ve ayrıntilı açıklamalar getirmektedir. Bu yaklaşımı bu teorinin açıklayıcı gücünü artırmaktadır. Aşağıda verilen örneklerde de görüleceği üzere birçok bilimsel çalışma Agnew’in bu iddialarını desteklemektedir.

Agnew yukarıdaki paragrafta ilk duyulduğunda çok da mantıklı gelmeyen bir iddiada bulunmakta ve aile bireyleri arasındaki nefretten bahsetmektedir. Özellikle anne-baba ve çocuk arasındaki bir nefretten bahsetmek çok mantklı görülmemektedir. Ancak bu iddia maalesef bilimsel çalışmalar ile ispatlanmıştır. Bu kapsamda Türkiye'deki lise öğrencilerin düşüncelerini araştıran Sankır kendilerine karşı saygıları ve güvenleri az olan ve birçok suç davranışını ve diğer sapma

\footnotetext{
${ }^{2}$ Bu bölümde beş yaşam alanındaki faktörlerin tamamı, onların bireyleri suça hangi şekilde ittiği veya suçtan koruduğu ve diğer faktörler ile olan etkileşimleri özet olarak ele alınmıştır. İlgili olanlar Agnew’in kitabına başvurmalıdırlar.
} 
Eker, A. (2016). Agnew'in suç ve çocuk suçluluğu genel teorisinin temel unsurları, suç önleme politikaları ve limitleri. International Journal of Human Sciences, 13(1), 1945-1968. doi:10.14687/ijhs.v13i1.3735

davranışlarını gerçekleştiren gençlerin anne babalarının kendilerini sevmediğini, istemediklerini, dövdüklerini, aşağılayıcı lakaplar taktıklarını ve kendilerine düşmanca muamele ettiklerini düşündüğünü tespit etmiştir. Sankır bu çalışmasının sonucunda ebeveynleri tarafindan sevilmediklerini ve istenmediklerini düşünen bu gençlerin öz saygısı yüksek olan gençlere nispeten "sigara, alkol ve uyuşturucu madde gibi bağımlılık yapan maddeleri daha fazla kullandıklarını, evden ve okuldan daha fazla oranda kaçtıklarını, kendi vücutlarına zarar verdiklerini, okul idaresiyle sorun yaşadıklarını ya da kolluk kuvvetleriyle başlarının derde girdiğini” bulmuştur. Suç ve diğer sapma davranışlarının ötesinde bu bireylerin intihara eğilimli olduklarını da bulmuştur (2014: 1330).

Glueck ve Glueck 1950 yllında 500 suçlu genci ve 500 suça karışmayan genci uzun yllar boyunca izleyerek yaptıkları bilimsel çalısmalarında "suçlu çocukların ailelerinden genellikle şiddet gördüklerini, reddedildiklerini ve düşmanca tavırlara muhatap olduklarını ve ailenin bu davranışının

\section{Şekil 1: Suça Doğrudan Etki Eden Ana Faktörler (5 Yaşam Alanı Etkisi)}

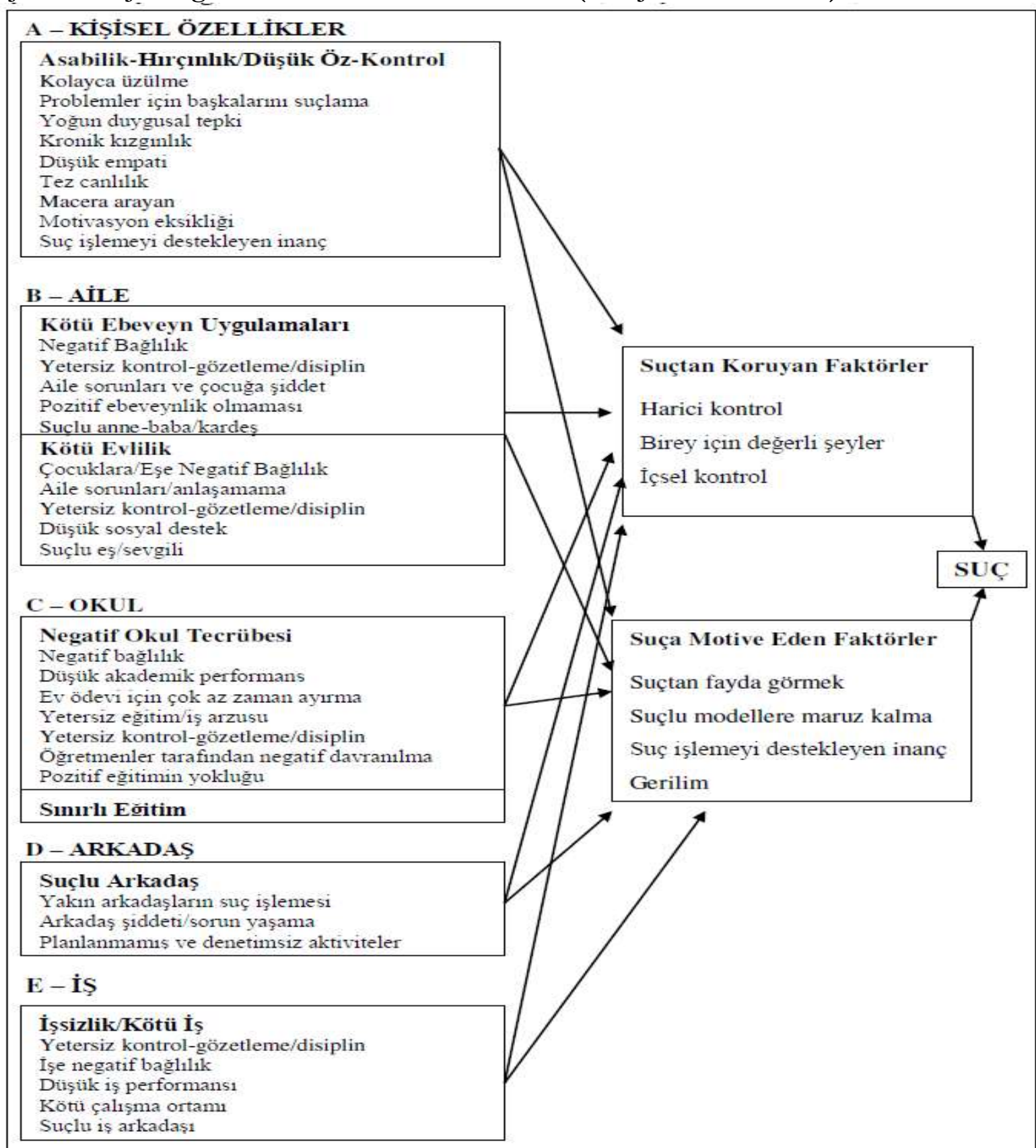

Kaynak: Agnew, (2005: 60). 
Eker, A. (2016). Agnew'in suç ve çocuk suçluluğu genel teorisinin temel unsurları, suç önleme politikalar1 ve limitleri. International Journal of Human Sciences, 13(1), 1945-1968. doi:10.14687/ijhs.v13i1.3735

suça iten çok kuvvetli bir neden olduğunu” bulmuşlardır (Hollist, Hughes, \&Schaible, 2009: 380). Devlet okuluna giden 182 lise öğrencisine (95 kı, 87 erkek) anket uygulayan Hay, gerçekleştirdiği bu çalışmasının sonucunda "anne-baba tarafindan fiziksel şiddet görmenin, reddedilmenin ve adaletsiz/orantısız cezaya çarpturılmanın gençlerin gerilimlerini arttırdığını ve suça dolaylı etki ettiğini" bulmuştur (2003: 113, 119). Amerika'daki gençleri inceleyen bu iki çalışma ile Türkiye'deki gençleri inceleyen Sankır'n çalışması nerede ise aynı sonuçları bulmuştur. Bu sonuçlar anne-baba etkisinin evrensel olduğunu ve birçok akademisyenin belirttiği gibi çocukları sevmenin, sevdiğini göstermenin ve sıcak ilgi duymanın çok önemli olduğunu göstermektedir. İletişim uzmanlarının çok sıklıkla belirttikleri gibi sıcak ilişkiler kurabilmek için karşıdaki kişiye onu sevdiğimizi söylemeliyiz.

$\mathrm{Bu}$ tartışma doğrultusunda bir araştırma yapan Zhang, Day, \& Cao yapmış oldukları analizlerinin sunucunda "aile yaşam alanının içerisinde bulunan anne-babaya bağlllık ve ebeveyn kontrolünün suça dolaylı etki" ettiğini bulmuşlardır (2012: 875). Hirschi de yazmış olduğu "Sosyal Bağ Teorisinde" bireylerin başkalarına karşı hissettikleri bağın, özellikle anne-babaya karşı hissedilen bağın- suçu önlemede çok önemli olduğunu iddia etmektedir. Daha da önemlisi, anne-baba özellikle gençlik yıllarında sürekli çocuklarının yanında olmayacağından dolayı arkadaşları ile yalnız kalan gençleri suç işlemekten anne-babaya olan bağlarının koruyacağını ve bu nedenle hayati öneme sahip olduğunu iddia etmektedir (2003).

Agnew'in teorisini destekleyen Hollist, Hughes, \& Schaible lise çağlarında olan 2000 gencin davranışlarını analiz etmişler ve "ebeveynleri tarafindan kötü muameleye maruz kalmış gençlerin yüksek oranda suç işlediklerini, bu suçlar arasında ciddi suçların da olduğunu ve uyuşturucu kullandıklanını" bulmuşlardır (2009: 384). Son olarak, anne-babalarını döven gençleri inceleyen Ibabe ve Jaureguizar, "genel olarak erkek çocukların annelerine şiddet uyguladığını (rapor edilen olayların \%92'sinde) ve bu erkek çocukların çoğunluğunun babalarının şiddet uygulayan kişiler olduğunu, bu geçlerin öz-güvenlerinin az olduğunu ve uyuşturucu kullandıklarını” tespit etmişlerdir (2010: 622).

Ayrıca, "olumlu anne-baba davranışları çocukların sosyal becerilerini ve sorunları legal yollardan çözme yöntemlerini geliştirmeleri için çok önemlidir ve bu davranışları görme şansları az olan çocuklar suça daha çok meyilli" olacaklardır (Agnew, 2005: 47). Bunlara ilaveten, "evli olmayan veya suçlu birisi ile evli olan bireylerin, özellikle bayanların suç işleme olasıllkları yüksek olacaktır. Çocuk sahibi olmak her ne kadar suçtan koruyan bir faktör olsa da bu gruba giren ve suçlu olan kişilerin evlilik dışı çocuk sahibi olma oranı yüksek olduğundan” çocuklarının olması birçoğuna maalesef olumlu etki yapmayacaktur (Agnew, 2005:48).

Yukarıda sıralanan tüm bilimsel çalışmalar ve Agnew'in Şekil 1'de özet olarak ifade ettiği iddiaları anne-baba tutumunun bireylerin çocukluk ve gençlik dönemlerinde suç işlemeleri veya işlememeleri üzerinde çok fazla etkisi olduğunu göstermektedir. Bu nedenle anne baba etkisinin araştırmacılar ve uygulayıcılar tarafından çok iyi anlaşılması ve pratik uygulamalarda kullanılması gerekmektedir.

c- Okul (Negatif Okul Tecrübesi ve Sinırlı Eğitim): Agnew suçluluğu doğrudan etkileyen faktörler olarak "okul ve öğretmenlere negatif bağlllı̆̆1, okulda zaman harcamaktan ve öğretmenlerden nefret etmeyi; bireysel kazancı düşüren ve gerilime neden olan düşük okul peformansını; ev ödevleri için daha az zaman harcamayı; okul bitirme ve iyi bir iş sahibi olma isteğinin düşük seviyede olmasını; öğretmenler ve okul yetkilileri tarafindan yetersiz disiplin ve gözetim uygulanmasını (yeterli disiplin kurallı yaşamayı ve olumlu davranışları öğretecek ve pekiştirecektir); çocukların derslerde ve hayatta başarılı olmalarını sağlayacak yeterlilikte öğretmenlerin olmamasını; ve öğretmenlerin negatif, sayg1 duymayan ve küçük gören davranışlar sergilemelerini” saymaktadır (2005:49-51). Bu kapsamda, 294 üniversite öğrencisinin hocalarının olumsuz tavırları karşısında ne hissettiklerini ve nasıl davrandıklarını analiz eden Moon, Hays, \& Blurton hocaların sergilemiş oldukları "duygusal cezalandırma ve ırk ayrımcıllğının önemli oranda suçlu davranışa neden oldukları" sonucuna ulaşmışlardır (2009: 103). "Okula bağllık ve ders çalışmaya ayrılan zamanın” gençlik suçluluğuna etkisini analiz eden Zhang, Day, \& Cao, bu 
Eker, A. (2016). Agnew'in suç ve çocuk suçluluğu genel teorisinin temel unsurları, suç önleme politikalar1 ve limitleri. International Journal of Human Sciences, 13(1), 1945-1968. doi:10.14687/ijhs.v13i1.3735

faktörlerin dolaylı olarak suça etki yaptığını bulmuşlardır (2012: 875). Ayrıca, “yetişkinler okulda olmamalarına rağmen araştırmalar bu kişilerin yetersiz eğitime sahip olmaları durumunda legal imkânlarının ve kaybedecek şeylerinin az olacağını, gerilimlerinin fazla olacağını ve suçtan elde edilecek faydanın bu kişiler için motive edici olduğunu” bulmuştur (Agnew, 2005:49-51). Bu açıklamalarında Agnew gelişimsel teorinin argümanlarını kullanmaktadır çünkü sadece okul dönemine odaklanmamakta, bunun yanısıra okul dönemindeki başarısızlıkların bireylerin ilerideki yaşamlarını da olumsuz olarak etkileyeceğini, iş bulma kapasitesini azaltacağını ve suç işleme olasılığının yüksek olacağını iddia etmektedir. Bu nedenle okula olan bağllık, okuldaki başarı ve kaliteli bir işe sahip olma birbirlerini etkileyen faktörler olarak bu teoride karşımıza çıkmaktadır.

d- Arkadaş (Suçlu Arkadaşlar): Bilimsel çalışmaların genel olarak ispatladığı üzere bireylerin suç işlemelerine en fazla etkisi olan faktör arkadaş etkisidir. Agnew, "yakın arkadaşların suç işlemesi” bireyleri suçtan alıkoyan "dış etkenleri (kınama, dışlanma, sevdiklerini kaybetme, vb.) zayıflatacağını çünkü arkadaşları ile beraber suç işleyen kişilerin suçlu da olsalar da kendilerini destekleyen bir çevreleri”" olacağını belirtmektedir (Agnew, 2005:51). Agnew burada çok önemli bir tespit yaparak suçlu arkadaşın sadece suça itmeyeceğini aynı zamanda gençlerin suçtan utunma duygularını da törpüleyeceğini de belirtmektedir. Aynı doğrultuda iddialarda bulunan Cohen (2003) "Suçlu Erkek Çocuğu" isimli eserinde ve Wolfgang ve Ferracuti de "Şiddetin Alt-kültürü" isimli eserlerinde gençlerin kendilerine ait alt-kültür oluşturacağını, bu alt kültür içerisinde suç işlemenin normal göründügünü ve suç işleyen gençlerin suçluluk duymadıklarını belirtmektedirler (Wolfgang ve Ferracuti, 2003: 156-158). Agnew bu noktada teorisine rutin aktiviteler teorisinin argümanlarını entegre etmekte ve gençlerin arkadaşları ile "organize edilmemiş ve büyükler tarafindan denetlenmeyen aktivitelere" katılmalarının ve diğer gençler ile beraber zaman harcamalarının suç işleme riskini artıracağını iddia etmektedir (Agnew, 2005:53). Bu iddiayı destekler mahiyette sonuçlara ulaşan Zhang, Day, \& Cao yapmış oldukları çalışmalarının sonucunda "gençlerin düşünce ve duygularının arkadaşları tarafindan etkilendiğini”" bulmuşlardır. Bu çalışmanın sonuçlarına göre "suçlu arkadaşlar ve arkadaşlar ile vakit geçirme genç suçluluğuna direk ve dolaylı etki etmektedir". $\mathrm{Bu}$ araştırmacılar genç suçluluğuna en fazla etkinin arkadaş etkisi ile şekillenen "suçun normal görülmesi” (suç lehine düşünceler) faktörü olduğunu da bulmuştur (2012: 874-875).

974 Türk üniversite öğrencisinin kişisel verilerini inceleyerek bu teoriyi test eden Özbay da benzer sonuçlara ulaşmışır. Özbay bu çalışmasında gerilim ve kızgınlık ile etkileşime geçen suçlu arkadaş etkisinin bireylerin rüşvet alma riskini artırdığını bulmuştur (2011).

Arkadaşların birbirlerine "zarar vermesi ve karşlıklı kavgalar" da bireyleri suç işlemeye itmektedir çünkü olumsuz modellere maruz kalan bireyler "orman kanunlarının” geçerli olduğu bir yerde yaşadıklarına ve suç işleyerek kendilerini koruyabileceklerine ve saygı kazanabileceklerine inanmak zorunda kalmaktadırlar (Agnew, 2005:52). Bu görüşleri destekleyen "Sokakların Kodu" isimli eserin yazarı Elijah Anderson "suçun ve gençler arasındaki şiddetin yoğun olduğu yerleşim yerlerinde yaşayan çocukların çevrelerinde gördükleri şiddetten ötürü korkusuz ve kavgaya hazır oldukları imajını vermek zorunda kaldıklarını, aksi halde diğer çocukların kendilerini tartaklayacaklarından korktuklarını" belirtmektedir (2003: 163).

Büyüklerin "arkadaş etkisi ile suç işleme” olasıllğı gençlere göre daha düşüktür. Ancak, "evli olmayan, işsiz veya düzenli bir işi olmayan bireylerin yaşamında arkadaşlarının genellikle merkezi bir rol" oynadığını iddia eden Agnew bu kişilerin yaşları büyük olsa da arkadaş etkisi ile suç işleyeceklerini belirtmektedir (Agnew, 2005: 53). Ayırıcı birliktelikler, rutin aktiviteler ve sosyal ögrenme teorisyenleri Agnew'in bu görüşlerini desteklemekte ve bu kişilerin sıklıkla dişarıda arkadaşları ile vakit geçireceğini ve arkadaşlarından etkilenerek suç işleme olasılıklarını artıracaklarını iddia etmektedirler (Sutherland ve Cressey, 2003; Cohen ve Felson, 2003, \&Akers, 2003).

e- $\dot{I}_{S}$ (İşsizlik ve Kalitesiz $\left.\dot{I}_{\boldsymbol{s}}\right)$ : “İşsizlik veya devaml olmayan ve kişiyi kendisine bağlamayan bir işte çalışmak (kadrolu olmayan garsonluk, beceri gerektirmeyen işçilik, vb.), iş ortamında yeterli disiplin ve gözetlemenin olmaması, işe bağlllık hissetmeme, düşük iş performansı 
Eker, A. (2016). Agnew'in suç ve çocuk suçluluğu genel teorisinin temel unsurları, suç önleme politikalar1 ve limitleri. International Journal of Human Sciences, 13(1), 1945-1968. doi:10.14687/ijhs.v13i1.3735

ve suç işleyen iş arkadaşı" gibi faktörler hem "suç işlemeye olan motivasyonu artırmakta, hem de "birbirleri ile etkileşimde bulunarak birbirlerinin etkisini arturmakta" ve öte yandan da suçtan alıkoyacak faktörleri azaltmaktadır. Ayrıca, "sağlıksız iş ortamı, iyi ücret vermeyen, çalışanlara sayg1 duymayan ve sürekli tehdit eden amirlerin olması, düşük prestijli ve yükselme imkânı olmayan işlerde çalışmak bireylerin işlerine olan bağlllıklarını azaltmakta, gerilimlerini ve eşitsizlik duygularını" artırmaktadır (Agnew, 2005:53-55). Bu görüşü destekleyen araştırmalar "gerilim yaşayan kişilerin bu gerilimlerinden kaynaklanan negatif duygularını suç işleyerek giderdiklerini ve suç işleyerek rahatladıklarını" bulmuşlardır (Vold, Bernard, \& Snipes, 2002: 149). Bu çalışmaya ilaveten, Swatt, Gibson, \& Piquero iş kaynaklı stresin polislerde alkol kullanma problemi yapıp yapmadığını araştırmak için Baltimore şehrinde görev yapan 940 polis ile anket çalışması yapmışlardır. Bu çalışma sonucunda "iş kaynaklı gerilimin hem kaygı/depresyona hem de kızgınlığa neden olduğunu" bulmuşlardır. İş kaynaklı "kayg1/depresyonun alkol kullanma problemine önemli oranda ve direk etki ettiğini, şahısların yaşadıkları gerilimin ise dolaylı etkisin olduğunu" görmüşlerdir. Genel inanışın aksine, polislerin yaşadığı "kızgınlığın alkol kullanımına önemli oranda etkisinin olmadığı" tespit edilmiştir. Bu arada, "aile ve arkadaşlanından destek gören polislerin daha az oranda kaygı, depresyon ve kızgınlık yaşadıklarını" bulmuştur. Bunlara ilaveten, "ruhsal/dini olarak rahatlama tekniklerini kullanan polislerin" daha az oranda alkol kullandıklarını tespit etmişlerdir (2007: 604-605).

Agnew'in bu son teorisini test eden nadir Türk araştırmacılardan birisi olan Özbay yukarıda bahsedilen Swatt ve arkadaşlarının çalışmasına benzer bir çalışmayı 974 Türk öğrenci örneklemi üzerinde yapmış ve kızgınlı̆̆ın alkol kullanımına önemli bir etkisinin olmadığını ancak sigara kullanımına ve öğrencilerin şiddete başvurmalarına önemli oranda etkisinin olduğunu bulmuştur (2014).

Özet olarak, bu beş yaşam alanını tekrar organize eden ve birbirlei ile ilgili faktörleri gruplayan Agnew kendi ifadesi ile gerçekten orijinal bir yaklaşım ortaya koymuştur. Şekil 1 incelendiğinde görüleceği üzere bu beş yaşam alanı birçok teorinin suça etkisi olduğunu savunduğu onlarca faktörü basitçe bir arada harmonize etmiş ve kavramayı kolaylaştırmıştır. Aşağıda bu faktörlerin birbirleri ile olan etkileşimleri anlatılacaktır.

\section{Karş11ıklı Etkileşim}

Agnew yukarıda belirtilen hayat alanlarının "sadece suça değil birbirlerine de direkt etki ettiğini” belirtmektedir. Bu etkileşimler aşağıdaki Şekil 2'de ayrıntılı olarak gösterilmiştir. Örneğin, çocukların "sinirlilik ve düşük öz-kontrol seviyeleri "kötü anne-baba davranışları tarafindan” direkt etkileneceği gibi bu karaktere sahip çocukların anne-babalanı ile olan bağları daha sorunlu olacak ve anne-babalar bu çocuklara karşı daha sert ve "şiddet içeren” davranışlar sergileyeceklerdir". Aslında "çocuğun karakterinin bir sonucu olan bu ebeveyn davranışı tekrar çocuğun karakterini şekillendiren" bir faktör haline gelecektir. Aşağıdaki şekilde gösterilen "yaşam alanlarının etkileşimleri bir ăg şeklinde bireyin etrafını çevirmekte ve hem bireyi hem de birbirlerini etkilemektedirler". Bu teoriye göre olumsuzluklar ağı "içerisinde sıkışan bir bireyin kurtulması ve normal bir yaşama başlaması çok zordur, ancak imkânsız değildir". Agnew kitabında "her bir yaşam alanının diğer yaşam alanlarına etkisinin olduğunu, ancak yaş ilerledikçe bazı alanların diğer alanlara olan etkisinin kaybolacağını veya derecesinin değişeceğini” iddia etmektedir (2005: 65-66, 84).

$\mathrm{Bu}$ teoriye göre önceki suçların tüm yaşam alanlarını etkileyerek suça dolaylı etkisi olmaktadır. Örneğin, suçlu bir kişinin iş ve evlilik yaşamı olumsuz etkilenecek, suçlu bir genç ailesi ve okul ile sorunlar yaşayacaktır. Ancak, Agnew bu görüşüne ilaveten "önceki suçların sonraki suçlara motivasyonu artırırken suçtan koruyan faktörleri kısıtladığını ve suçlu davranışlara direkt etkisinin olduğunu" iddia etmektedir. Başka bir ifade ile olumlu etkileri azatmakta ve olumsuzları artırmaktadır. Örneğin, "önceki suçlarında yakalanmayan ve maddi kazanç sağlayan bireyler sonraki suçlar için motive olacaklardır". Agnew'in yapmış olduğu bu tespit gerçekten çok doğru ve önemli bir tespittir çünkü suçluları suç işlemeye motive eden faktörlerden bir tanesi de maddi kazanç sağlanması ve yakalanma riskinin az olmasıdır. Ancak yazar bu noktada bir önceki iddiasının tam 
Eker, A. (2016). Agnew'in suç ve çocuk suçluluğu genel teorisinin temel unsurları, suç önleme politikalar1 ve limitleri. International Journal of Human Sciences, 13(1), 1945-1968. doi:10.14687/ijhs.v13i1.3735

aksi gibi görünen başka bir argümanı belirterek suçlulara ait çok önemli tespitte daha bulunmaktadır. Agnew "yakalanan suçluların da suç işleme olasılıklarının artacağını çünkü "kötü insan" olarak damgalanan bu kişiler üzerinde "harici koruyucu etkenlerin" etkisinin az olacağını" iddia etmektedir. Ayrıca sabıkalı olmalarından dolayı bu kişilerin iş bulma ve evlilik yapma olasılıkları daha az olacaktır (2005: 87-89). Damgalama teorisyenleri bu görüşü desteklemekte ve "damgalamanın negatif etki yapacağını, kişiyi toplumdan soyutlayacağını, öz-güvenini azaltacağını ve kişinin daha fazla suç işlemesine neden olacağını” belirtmektedirler (Matsueda, 2001: 223).

Şekil 2: Yaşam Faktör Gruplarının Karşılıklı Etkileşimi

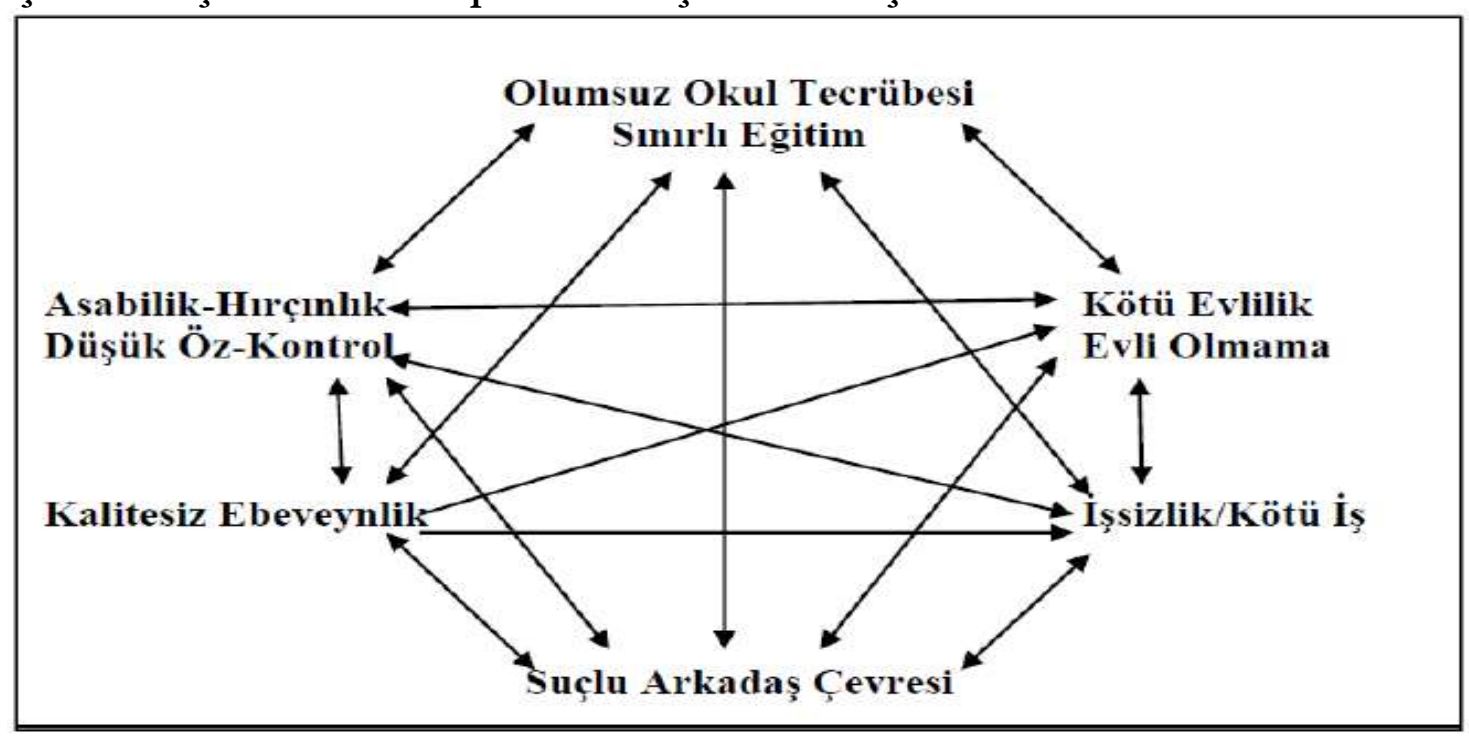

Kaynak: Agnew, (2005: 66).

Ancak "olasılık" kelimesini özellikle kullanan Agnew "suç işlemenin her zaman yeni suçlar işlemeye neden olmadığını, bazı bireyler suç işlemeye devam ederken diğerlerinin bıraktığını" belirtmektedir. Bu bireysel farklılığın beş nedeni sıralanmaktadır ve ilk üç tanesi suç işleme ihtimalini artırırken dördüncü faktör tekrar suç işleme olasıllğını azaltmaktadır: "(a) Suça Tepki Vermeme: bunun iki nedeni sıralanmaktadır: yetersiz denetim nedeni ile suçun bilinmemesi ve bilinse dahi müdahale edilmemesi durumudur. Özellikle anne-babanın suça tepki vermemesi önemli oranda olumsuz etki yapmaktadır.(b) Sert ve Dışlayıcı Tepki: suç işleyen birey dışlanır, damgalanır ve kınanır. Bu kısır döngüye kapılan, legal imkânları ve olumlu sosyal ilişkileri kısıtlanan bireylerin suç işleme olasıllğı artar. (c) Suçun Onaylanmasi/Desteklenmesi: bireyin işlediği suçun masum gösterilmesi ve bireyin haklı çıkarilması durumudur. (d) Suçu Şiddetle Reddetmek ama Sucluyu Kabul Etmek: suçlu davranışa ciddi bir tepki verilmekte ancak suçlu kişi sıcak bir şekilde kabul edilmektedir". Yukarıda da belirtildiği üzere ilk üç tepki şekli bireyin yaşam alanlarının olumsuz etkisini artıracak ve bireyler "çifte darbe" göreceklerdir. Ancak dördüncü tepki şeklinde "suçun kendisinin yanlış olduğuna vurgu yapılırken birey desteklenmektedir". Bu durumda bireyin "tekrar suç işleme olasıllğı" azalacaktır. (e) Son olarak, bireylerin karakteristik özellikleri bir suçtan sonra tekrar suç işleyip işlemeyecekleri üzerinde çok etkili olacaktır. "Öz-kontrolü düşük, hırçın, başkalarının mağduriyetine ve duygularına önem vermeyen, heyecan peşinde koşan ve çevresinden destek görmeyen bireyler işlenen suçtan çok fazla haz almakta ve yeni suçlar işlemektedirler. Fakat bu olumsuz karakter özelliklerine sahip olmayan bireyler suç işlemiş olsalar bile bu suçtan çok fazla haz almamakta ve kendilerini "suçlu ve tedirgin" hissetmektedirler. Bu nedenle tekrar suç işlemek için yüksek motivasyonları olmamaktadır" (Agnew, 2005: 100-101).

Bilimsel çalışmalar Agnew’in bu iddiasını desteklemektedir. Bu teoriyi çok kapsamlı bir şekilde test eden Zhang, Day, \& Cao gerçekleştirmiş oldukları araştırmalarında beş yaşam alanının suça etkisi olup olmadığını analiz etmişler ve "beş yaşam alanındaki bazı faktörler ile genç suçluluğu 
Eker, A. (2016). Agnew'in suç ve çocuk suçluluğu genel teorisinin temel unsurları, suç önleme politikaları ve limitleri. International Journal of Human Sciences, 13(1), 1945-1968. doi:10.14687/ijhs.v13i1.3735

arasında güçlü bir bağ” bulmuşlardır. Buna ilaveten“beş yaşam alanındaki etkili bulunan faktörlerin genç suçluluğuna önemli oranda direkt ve dolaylı etki ettiklerini, dolaylı etkilerini suça iten nedenler ve suçtan koruyan faktörler üzerinden yaptıklarını” bulmuşlardır. Bu bilimsel çalışma Agnew’in teorisinin gençlik suçlarında meydana gelen değişikliklerin \%44’ü gibi çok yüksek bir oranını açıladığını bulmuştur (2012: 874-875).

\section{Bireylerin Yaşlarına Göre Yaşam Alanlarının Değişen Etkileri}

Yukanda özet olarak anlatılan her bir yaşam alanı ve onlanın içerisindeki etkenler bireyler üzerinde çok etkilidirler. Ancak her bir faktörün etkisi farklı yaşlarda değişmektedir. Örneğin, yukarıda da anlatıldığı gibi çocukluk ve ilk gençlik yıllarında çok önemli olan arkadaş etkisi (kendini kabul ettirme, taklit, vb.) yaş ilerledikçe tesirini kaybetmektedir. Faktörlerin etkilerinde meydana gelen bu değişimler üç sebeple açıklanmaktadır. Birinci olarak, "yaşam alanının ve içerisindeki faktörlerin o anki zamanda bireyin hayatında oynadığı rol ve bireyin o anki etkiye verdiği önem" çok önemlidir. Örneğin, anne-babanın çocukluk döneminde bireyler üzerindeki etkisi çok fazladır çünkü çocuk genellikle anne-baba ile beraberdir. Ancak, birey büyüdükçe ve evden ayrı olarak başkaları ile zaman harcadıkça ailenin etkisi azalır ve diğerlerinin önemi artmaya başlar. İkinci olarak, "her bir hayat alanının etkisi diğer hayat alanlan ile rekabet halindedir ve hangisi daha kuvvetli ise bireyin davranışına o etki eder". Örneğin, okula gitmeye başlayan bir çocuk üzerinde hem anne-baba hem de okul, öğretmenler ve arkadaşlar etki etmeye çalısıırlar. Hangisinin etkisi daha kuvvetli olursa birey o yöne gidecektir. Üçüncü olarak, "hangi yaşam alanının birey üzerinde etkili olacağ1 kişinin o zamanki karakteri, becerileri ve ilgi alanları tarafindan belirlenmektedir". Örneğin bir genç üzerinde arkadaşları ve ailesi etkili iken büyüdükçe iş alanı etkili olacaktır (Agnew, 2005: 56). Benzer şekilde, Sullivan bireylerin yaşları ilerledikçe "risk ve koruyucu faktörlerin" değiştiğini bu nedenle de araşurmacıların suçun nedenini ve önlenmesi çalışmalarında gelişimsel kriminolojinin yaklaşımını takip etmeleri gerektiğini iddia etmektedir (2006: 292). "Gelişimsel Kriminolojiyi”" savunan Sampson ve Laub (2003), Moffitt (1993) ve Farrington (2003) gibi teorisyenler yaş ilerledikçe ve bireyler olgunlaştıkça kişinin düşünce şeklinin, ilgi alanlarının, etkilendikleri faktörlerin ve davranışlarının değiştiğini iddia etmektedirler. Bu nedenle daha çocukluk yıllarından itibaren olumlu yaşam alanları, özellikle aile yaşam alanının olumlu etkileri geliştirilmeli ve bireyler diğer yaşam alanlarının olumsuz etkilerine karşı koruma altına alınmalıdırlar.

Agnew bireylerin hayatlarını kabaca üç ana bölüme ayırmaktadır: cocukluk, gençlik ve yetişkinlik. Aşağıdaki Şekil 3'de üç yaşam bölümünde hangi faktörlerin bireyleri suça motive ettiği gösterilmektedir. Çocukluk ve gençlik dönemlerinde aynı dört faktör daha çok etkili iken yetişkinlik döneminde bu faktörlerin sayısı altı tane olmakta ve olumsuz okul tecrübesinin etkisi kaybolmaktadır. Örneğin, "çocukluk yıllanında olumsuz anne-baba ve bireysel özellikler en etkili faktör iken gençlik yıllarnnda anne-baba etkisi azalma göstermekte ve fakat arkadaş etkisi artmaktadır". Yetişkinlik döneminde dört tane çok etkili faktör vardır ve gençlik dönemine ilave olarak "evlilik durumu ve iş hayatı" etkisini arttırmaktadır. Aşağıdaki şekilde etkisi çok olan faktörler kalın çizgi ile az veya orta etkili faktörler ise ince çizgi ile gösterilmiştir (Agnew, 2005: 57). Şekil 3 dikkatli bir şekilde incelendiğinde gelişimsel teorinin ve yaşam boyu suçluluk teorilerinin ana argümanlarının çok anlaşılır ve düzenli bir şekilde organize edildiği görülmektedir. Bu şekil bireye çocukluk çağından itibaren hangi değişkenlerin etki ettiğini ve daha da önemlisi bu etkinin derecesini çok güzel özetlemektedir. Bu şekilde sıralanan çoğu faktörler aslında gelişimsel kriminolojiyi savunan teorisyenlerin "dönüm noktası" olarak tarif ettiği etki alanlarıdır. Örneğin, çocukluk çağından ayrilıp gençlik çağına giren bir birey okul ve arkadaş etkisi ile karşılaşmaktadır. Okuldan mezun olan kişiler ise iş ve evlilik dönüm noktaları ile karşılaşmaktadırlar bu teoriye göre. 
Eker, A. (2016). Agnew'in suç ve çocuk suçluluğu genel teorisinin temel unsurları, suç önleme politikaları ve limitleri. International Journal of Human Sciences, 13(1), 1945-1968. doi:10.14687/ijhs.v13i1.3735

Şekil 3: Yaşam Alanlarının Çocukluk, Gençlik ve Yetişkinlik Evrelerinde Suça Etkisi (Yüksek Etkiler Kalın Çizgi İle Gösterilmiştir)

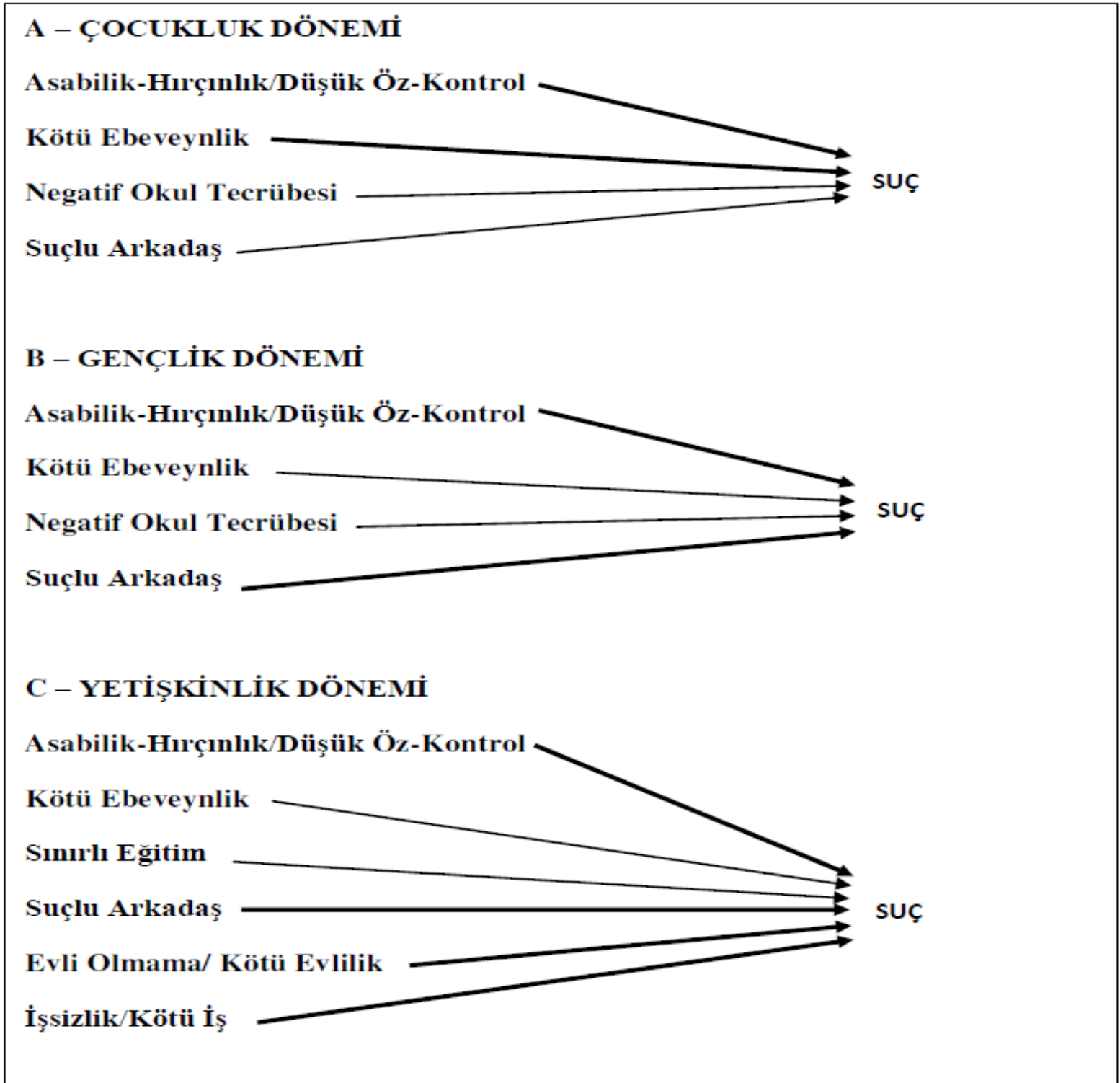

Kaynak: Agnew, (2005: 58).

Moffitt'in (1993) çok meşhur ve genel kabul görmüş olan "yaşam boyu suçluluk ve sadece gençlik dönemlerinde suç işleme” kuramının geçerli olduğunu belirten Agnew, "düşük öz-kontrol, sinirlilik, asabilik, kötü huylu olma ve küçük yaşlarda kötü anne-baba davranışlarına maruz kalmanın” yaşam boyu suçlu olma ihtimalini çok yükselteceğini iddia etmektedir. Agnew'e göre bu kişisel ve ailevi yaşam alanları bireylerde "sürekli bir olumsuz etki" bırakacaktır. Ayrıca, bu temel faktörlerin bireylerin ileriki yaşlarında karşılaşacağı "okul, arkadaş ve eş seçimi ve iş kalitesini şekillendirecek güçte olduklarını, bu nedenle de küçük yaşlarda karşılaştıkları olumsuz davranışların suça motive edici faktörleri artırdığını ve suçtan koruyucu faktörlerin de gelişmemesine neden olduklarını" belirtmektedir. Bu olumsuz etki ile şekillenen "okul, arkadaş, evlilik ve iş yaşam alanları" bireyin yaşı ilerledikçe ters etki yapacak ve "öz-kontrol ve sinirlilik-asabilik gibi bireysel özelliklerinin ve anne-baba ile olan ilişkilerin daha da olumsuz olmasına ve suçtan koruyucu faktörlerin daha da azalmasına" neden olacaklardır. "Olumsuzluklar ağı içerisine sıkışıp kalan" bireylerin bu durumdan kurtulmaları çok zor olacaktır. Örneğin, "ailesinin sosyo-ekonomik seviyesi 
Eker, A. (2016). Agnew'in suç ve çocuk suçluluğu genel teorisinin temel unsurları, suç önleme politikaları ve limitleri. International Journal of Human Sciences, 13(1), 1945-1968. doi:10.14687/ijhs.v13i1.3735

düşük olanların, erkeklerin ve siyahî olanların ${ }^{3}$ çocukluk yaşlarında çok fazla olumsuzluk yaşama ihtimalleri olduğundan ileriki yaşlarında da suçlu olarak hayatlarına devam etme olasılıkları yüksek olacaktır" (Agnew, 2005: 167-168).

Agnew "gençlik dönemlerinde suç işleyen bazı bireylerin ileriki yaşlarda suç işlemeyi bırakttğını, bu durumun da bu kişilerde "düşük öz-kontrol, sinirlilik-asabilik-kötü huylu olma ve küçük yaşlarda kötü anne-baba davranışlarına maruz kalma” gibi sorunların olmadığını gösterdiğini ve bu durumun bilimsel çalışmalar ile de kanıtlandığını" iddia etmektedir (2005: 169). Moffitt’in gelişimsel teorisinde belirttiği üzere bu bireyler gençlik dönemlerinde "bedenleri gelişirken zihinsel gelişimleri daha yavaş olmakta, daha az anne-baba kontrolü ve etkisi yaşarlarken daha fazla arkadaş etkisine" maruz kalmaktadırlar (1993: 686-687). Bu durumu yaşayan gençler hayatlarının bu dönemlerinde daha fazla suç işlemektedirler. Ancak yaşları ilerledikçe "zihinsel olgunlaşmaları tamamlanmakta ve arkadaş etkisı” azalmaktadır. Bu nedenle de gençlik döneminin bitiminde bu kişiler "Öz-kontrollerini yükseltmekte, sinirli ve asabi tavırları terk etmekte, evlenmekte, işine bağlanmakta ve suçlu kişiler ile bağını azaltmaktadırlar”. Bu nedenlerden dolayı bu bireyler suç işlemeyi bırakmakta ve normal bir yaşam sürmeye başlamaktadırlar (Agnew, 2005: 169).

\section{Aynı Olumsuz Faktörlere Maruz Bireylerin Farklı Tepkileri}

Şikago Okulu ekolünü, sosyal organizasyonsuzluk teorisinin ve sosyal öğrenme teorilerinin argümanlarını takip eden ve savunan teorisyenler ve akademisyenler bireyin yaşadığı aile ve çevrede suçun çok olması ve bireyin çevresinden, özellikle yakın çevresinden suçu öğrenmesi durumunda o bireyin suç işleme olasıllğının çok yüksek olduğunu belirtmektedirler (Shaw \& McKay, 2003; \& Akers, 2003). Ancak, aynı olumsuz yaşam alanlanına ve şartlara maruz kalan bireylerin bazıları suç işlemekte iken diğer bireyler tüm olumsuzluklara rağmen suç işlememektedirler. Smith ve arkadaşları (1995) suç üreten bir ortamda yetişmesine rağmen suç işlemeyen bu gençlere "dirençli gençler" (resilient youths) demektedirler. Aynı olumsuz durumlarda yaşayan ve suça iten motivasyonlara yüksek derecede maruz kalan bazı bireyler suç işlemekte iken aynı şartlardaki diğer bireyler kendilerini suç işlemekten nasıl koruyabilmektedirler? Agnew bu sorunun cevabının "suçu anlamada ve önlemede çok önemli" olduğunu çünkü "bazı kişilerin suça motive eden faktörlere niçin ve nasıl karşı koyduklarının anlaşılması durumunda diğer kişilerin de bu özelliklerini geliştirmeye yardımc1 olacak programların tasarlanabileceğini” belirtmiştir. Bu nedenle de bu bölümün teorisinin çok önemli bir parçası olduğunu belirtmektedir (Agnew, 2005: 111).

$\mathrm{Bu}$ önemli soruyu teorisinde cevaplandıran Moffitt beş neden saymaktadır: "gecikmiş ergenlik dönemi, olumlu ve gençler tarafindan saygı duyulan modellerin varlığı, suçu öğrenme imkânlarını kısıtlayan bir çevre, anti-sosyal arkadaş çevresinden uzak durmalarını sağlayan karakter ve dört faktörün de bir arada bulunması" (1993: 689-690).

Agnew ise bu sorunun cevabını bu makalenin başından buraya kadar izah ettiği argümanlarını özetleyerek vermektedir: "yaşam alanlarndan her birisinin birey üzerindeki etkisi diğer alanlarn o birey üzerindeki tesirine göre şekillenmekte, artmakta veya az̧almaktader" (2005: 110). Başka bir ifade ile "suça iten bir "neden" diğer olumsuz nedenlerin de var olması durumunda büyük ihtimalle suça sebep olacaktır. Öte yandan, suçtan koruyan bir faktörün varlığı olumsuz faktörlerin etkisini düşürecek ve bireyin suç işleme olasıllŏ̆nı azaltacaktır. Örneğin, kötü ve yetersiz anne-babanın bireyin üzerindeki negatif etki seviyesi bireyin asabilik durumu, öz-kontrol seviyesi, okuluna ve öğretmenlerine bağlllı̆̆1 ve suç işleyen bir arkadaş çevresine sahip olup olmadı̆̆1 gibi diğer faktörler tarafindan belirlenecektir. Eğer bir kişinin düşük öz-kontrolü, suçlu arkadaş çevresi ve olumsuz okul tecrübesi varsa, bu faktörlerin olumsuz etkileri anne-babanın olumsuz etkisini daha da artırarak kişinin suça yönelme olasılığını önemli oranda yükseltecektir" (2005: 111-112). Bu durumun aksine, "annebabası ile çok iyi bir iletişim ve bağ geliştiren bireyin suç işleme olasıllğı düşük öz kontrole, suçlu

\footnotetext{
${ }^{3} \mathrm{Bu}$ kişiler genellikle legal imkânlara sahip olmadıklarından dolayı olumsuzluklarla karşılaşmalarının daha sık ve yoğun olduğu ve ırk ile ilgili olmadığı yazar tarafından belirtilmiştir.
} 
Eker, A. (2016). Agnew'in suç ve çocuk suçluluğu genel teorisinin temel unsurları, suç önleme politikalar1 ve limitleri. International Journal of Human Sciences, 13(1), 1945-1968. doi:10.14687/ijhs.v13i1.3735

arkadaşlara ve çevreye sahip olmasına rağmen düşük olacaktır çünkü anne-babaya duyulan güven ve sevgi o kişi üzerindeki olumsuz etkileri dengeleyecektir” (2005: 113). Bunlara ilaveten, yukarıda da belirtilen bir argümanı Agnew tekrar hatırlatmakta ve "her bir faktörün sadece suçu değil diğer faktörleri de etkilediğini ve onların daha pozitif veya daha negatif olmasına neden olduğunu" belirtmektedir (2005: 118). Agnew’in de belirttiği gibi bu bölüm gerçekten bu teorinin en önemli kısmıdır. Aslında tüm teorilerin en önemli ilgi alanıdır çünkü Gottfredson ve Hirschi gibi teorisyenlerin de belirttiği gibi suça motive eden veya zorlayan firsatlar çok fazladır ve kolaylıkla ulaşılabilirler. Agnew'in bu teorisinden anlaşılacağı üzere bu duruma maruz kalan bireyler ancak kendilerini çevreleyen faktörlerin ortak etkisi sayesinde suç işlmekten uzak kalabileceklerdir. $\mathrm{Bu}$ nedenle yukarıdaki etkileşimlerden de anlaşılacağı üzere herbir yaşam alanı ve faktör önemlidir ve Agnew'in tavsiye ettiği gibi bu faktörlerin olumsuz yönleri azaltulmalı ve olumlu etkileri artrrlmalıdır.

Bunlara ilaveten, günümüzdeki birçok teorisyen suça iten nedenlerin tam olarak açıklanabilmesi için "bireylerin karakterlerini inceleyen psikolojik teoriler ile kişinin yaşadığı çevrenin etkisini inceleyen sosyolojik teorilerin beraber düşünülmesi” gerektiğini iddia etmektedirler (Agnew, 2005: 116). Agnew gerilim teorisyenlerinin bu iddiasını desteklemekte ve "faktörlerin etkileşimi üzerine çok fazla bilimsel çalışmanın yapılmadığını ve gerçekleştirilen bazı araştırmaların bu faktörler arasındaki "etkileşimi”" tespit etmekten uzak olduğunu” iddia etmektedir. Bunun nedeninin ise "yetersiz istatistikî metot kullanılması ve daha kapsamlı veri toplama yöntemleri yerine anket yönteminin kullanılması olduğunu ve bu yetersiz yöntemlerin aslında var olan birçok etkileşimi tespit edemediklerini”" iddia etmektedir (2005:114).

\section{Harici Faktörler: Biyolojik ve Çevresel Faktörlerin Yaşam Alanlarına Etkileri}

Agnew buraya kadar verilen bilgiler ile teorisinin önemli bölümünü tamamladığını, bireylerin davranışlarının içerisinde bulundukları beş yaşam alanı tarafindan şekillendiğini ve ayrıca bu yaşam olanlarının birbirlerini de etkilediğini anlatmıştır. Ancak çok önemli bir sorunun daha açılanması gerektiğini belirtmektedir: "bir bireyin yaşam alanmm kalitesi hangi faktörlerce belirlenmektedir? Başka bir ifade ile suçu direkt etkileyen beş yaşam alanını hangi harici faktörler şekillendirmektedir? Örneğin, bir kişinin kötü anne-babasının olmasını, düşük öz-kontrollü ve asabi olmasını ilk başta hangi faktörler etkilemektedir? Agnew, şu ana kadar anlatılan "karşılıklı etkileşim iddiasının bu sorunun sadece belli bir kısmına cevap olabildiğini, ancak yaşam alanlarına etkisi olan harici faktörlerin (biyolojik ve sosyal çevre vb.) etkisinin eksik kaldığını" onların dâhil edilmesi ile yukarıdaki sorunun cevaplanabileceğini belirtmektedir (2005: 139). Agnew bu noktada gerçekten takdire şayan bir yaklaşım sergilemiş ve birçok akademisyen tarafindan eleştirilen "dogmatik ön kabul" tuzağına düşmemiştir. Daha da açıklayacak olursak, Agnew yukarıdaki ifadeleri ile bazı teorilerin düşük sosyoekonomik durumun bireyi suça motive ettiği iddiasında bulunduğunu ancak düşük sosyoekonomik duruma hangi nedenlerin etkisi olduğunu ve bireyin neden o durumda olduğunu açıklamadıklarını belirtmek istemektedir. Bu ilk olumsuzluklara neden olan faktörler aşağıda belirtilmiştir.

$\mathrm{Bu}$ teoriye göre ulusların genel ekonomik durumları gibi bireyi etkileyen birçok harici etken bulunmaktadır ve bu geniş dairedeki etkenler bireyin yakın çevresini saran faktörleri etkilemektedirler. Ancak bu teoriye sadece yakın çevredeki en önemli faktörler dâhil edilmiştir ve bu faktörlerin başında da "biyolojik ve sosyo-demografik faktörler (bireyin yaşı, cinsiyeti, etnisitesi, anne-babasının sosyo-ekonomik durumu, içerisinde yaşanılan mahallenin özellikleri)" gelmektedir. Biyolojik özellikler "genetik aktarım ile ya da "biyolojik kazalar" (annenin yetersiz sağlık durumu ve hamilelikte uyuşturucu-alkol-sigara kullanması, doğum sırasında oluşun beyin hasarı) ile ortaya çıkmaktadır”. Genetik aktarım konusunda birçok farklı görüş bulunmaktadır ancak genetik aktarımın varlığını bulan bilimsel çalısmaları kabul eden Agnew "belli bir oranda anne-babanın özeliklerinin" genetik olarak çocuğa geçtiğini iddia etmektedir. Genetik olarak ve sonradan meydana gelen biyolojik eksiklikler "sinir sistemini ve insan beyninin fonksiyonlarını" olumsuz etkilemektedir. Örneğin, "serotinin beyin hücrelerinin birbirleri ile iletişimini sağlamaktadır ve yeterli 
Eker, A. (2016). Agnew'in suç ve çocuk suçluluğu genel teorisinin temel unsurları, suç önleme politikaları ve limitleri. International Journal of Human Sciences, 13(1), 1945-1968. doi:10.14687/ijhs.v13i1.3735

oranda bulunmaması durumunda beynin "ket vurma" özelliğini zayıflatacak ve bu durum da bireyin "dürtüsel" ve düşünmeden hareket etmesine" neden olacaktır (2005: 140-141).

Bireylerin sosyo-demografik faktörleri başta asabilik ve düşük öz-kontrolün gelişmesine neden olacaktır. Örneğin, "erkekler asabilik ve hırçınlıkta kızlardan daha ileride iken öz-kontrol sağlamada daha geridedirler". Agnew bu duruma iki muhtemel açıllama getirmektedir: "erkeklerin biyolojik yapiları ve toplumun farklı tutumu". Bunlara ilaveten, anne-babanın "sosyo-ekonomik durumunun" bireyin hırçınlık ve öz-kontrol seviyesine olan etkisi Agnew tarafindan inandırıcı bir şekilde izah edilmiştir. "Sosyo-ekonomik durumu yeterli olmamasından dolayı şehirlerin gelişmemiş bölgelerinde yaşayan, kendi anne-babalarından olumsuz davranışlar görmüş, maddi veya diğer herhangi bir sebepten dolayı gerilim yaşayan ve yeterli anne-babalık için gerekli bilgi ve karaktere sahip olmayan ebeveynler" çocuklarına "iyi örnek olamayacak, zaman ayıramayacak ve olumsuz davranışlar sergileyecektir". Bu "ortamda yetişen bireyler de hırçın ve düşük öz-kontrollü” olacaklardır (2005: 142-145). Bu görüşü destekleyen Glueck ve Glueck 500 suçlu gencin ailelerini incelediklerinde "suçlu çocukların anne-babalarının zihinsel sıkıntı yaşadığını, alkol kullandığını ve suç işlediğini”" bulmuşlardır (2003: 44). Agnew'in teorisini destekler mahiyette bir araştırma yapan Schroeder, Hill, Haynes \& Bradley "genel olarak fakir kişilerin yaşadığı bölgelerde ikamet eden 2,402 düşük gelirli kadının” sağlık durumu ile suç ilişkisini araştırmışlardır. Bu çalışma Agnw’in teorisini destekleyen sonulara ulaşmış ve "sağlık durumları kötü olan kadınların yaşamakta oldukları "kayg1 ve depresyonun" suç işlemeye başlamalarına ve işledikleri suçların artmasına" neden olduklarını bulmuşlardır (2011: 21, 23). Bu çalışmanın sonucu Agnew'in "suç işleyen kadınlar anne olmaları durumunda çocuklarına gerekli disiplini veremeyecek ve olumlu örnek olamayacaklardır, bu nedenle de bu kişilerin çocuklarının suçlu olma ihtimallerinin yüksek olduğunu" iddia ettiği görüşünü desteklemektedir. Benzer bir çalışmayı gerçekleştiren Stogner ve Gibson "sağlık sorunları yaşayan ve bu sorunlar nedeni ile arzularını gerçekleştiremeyen" gençlerin suç işleme oranlarını test etmişlerdir. Bu çalışmaları sonucunda "sağlık sorunlarından kaynaklanan gerilimin şiddet içermeyen suçların işlenmesinde önemli etkisinin” olduğunu bulmuşlardır (2010: 1156).

Son olarak, "kolej hazırlık kursuna gidemeyen, kalabalık sinıf ve okulda olan, öğretmenlerinden yeterli zaman ve ilgi göremeyen, diğer öğrencilerin derslere ilgisizliğine şahit olan, okul tarafindan motive ve disipline edilemeyen ve suçlu arkadaşlar ile dolaşan bireylerin negatif okul tecrübesi geliştirmesi” kuvvetle muhtemel olacaktır. Okula olan bu ilgisizlik diğer yaşam alanlarını da olumsuz etkileyecektir ve buraya kadar belirtilen tüm olumsuz faktörler ile ile etkileşime geçerek bireyin kaliteli, devamlı ve yeterli gelir sağlayan bir iş sahibi olmasını engelleyecektir. Örneğin, uzun nesiller boyunca beş yaşam alnındaki hemen hemen tüm olumsuzluklara maruz kalmış siyahî kişilerin dikkate değer bir kısmı kaliteli iş bulamamakta, aşırı derecede gerilim yaşamakta ve toplum tarafından tembel, asabi ve öz-kontrolü düşük bireyler olarak görülmektedirler (Agnew, 2005: 145147).

\section{Suç Önleme için Öneriler}

Genel olarak uygulanmakta olan suç önleme yöntemi "bireylerin yakalanması ve hapse atılmasıdır. Ancak bu durum suçun nedenlerini ortadan kaldırmayacağı gibi bu nedenleri daha da kötüleştirecektir". Agnew birçok araştırmanın "suç işleyen kişileri cezaevlerine atarak uzun süreli toplumdan uzaklaştırmanın suç işlemeyi azaltmadığını ve hatta artırdığını bulduklarını" belirtmektedir (2005: 189). Genel inanışın tersine olan bu durumun Agnew'e göre üç nedeni vardır: "Birinci olarak, suçların büyük bir çoğunluğu cezasız kalmakta, suçlular yakalanmamaktadır. Bu durumda yakalanan bireyler kendilerine haksızlık yapıldığına, polisin ayrımcilık yaptığına ve yakalama sırasında polisin küçük düşürücü davrandığına, verilen cezanın adaletsiz ve orantısız olduğuna inanmaktadırlar. Bu inanış cezanın caydırıcilık etkisini ortadan kaldırmakta ve bireylerin daha fazla gerilim hissetmelerine neden olmaktadır.İkinci olarak, yakalama ve ceza verme suça neden olan diğer birçok olumsuz faktörün etkisini ortadan kaldırmamaktadır. Örneğin, tutuklanma ailevi sorunları, okul ve iş ile ilgili sorunları ve öz-kontrol ile ilgili sorunları çözmeyecek ve içinde bulunulan sıkıntılı durumu ortadan kaldırmayacaktır. Son olarak, tutuklanan kişilerin sisteme ve 
Eker, A. (2016). Agnew'in suç ve çocuk suçluluğu genel teorisinin temel unsurları, suç önleme politikalar1 ve limitleri. International Journal of Human Sciences, 13(1), 1945-1968. doi:10.14687/ijhs.v13i1.3735

topluma kızgınlıkları artacak, işini kaybedecek, kalıcı iş bulmaları zorlaşacak, boşanma dâhil ailevi sorunlar ortaya çıacak ve diğer suçlular ile etkileşim oranı daha da artacaktır” (2005: 189-190).

Agnew bu aşamada çok güzel bir tespit yaparak yukarıdaki davranışların "kısır döngüye" neden olacağını çünkü “asabi, düşük öz-kontrollü, suçlu bir çevrede yaşayan ve daha önce suç kaydı olan kişilere karşı polislerin "önyargılı" olacaklarını ve sert davranacaklarını, tutuklanma oranlarının yüksek olacağını ve aldıkları cezaların sonraki suçlu davranışlarını" daha da artıracağını belirtmektedir. Ancak, "yüksek öz-kontrollü ve suç kaydı olmayan ve iyi bir çevrede yaşayan bireyler polis veya diğer yetkililer tarafindan sergilenen bu olumsuzluklara" hiç veya daha az muhatap olacaklardır. Bu kişiler tüm "suçluların anında yakalandığına, polisin nazik ve adil olduğuna ve adil bir ceza sisteminin var olduğuna inanacaklardır. Bu nedenle de bizzat kendileri almasa bile verilecek cezalar toplumdaki bu özelliklere sahip bütün bireylerin sonraki suç işleme riskini ciddi oranda düşürecektir (2005: 190-192). Ancak Agnewe göre ilk gruptaki bireyler daha fazla suç motivasyonuna sahip olacaklardır.

Yukarıda izah edilen temel tartşmaları değerlendiren Agnew, tutuklama ve cezaların etkinliğini artırmak için dört önemli öneride bulunmaktadır. Birinci olarak, "polis birimleri son zamanlarda etkinliği ispatlanan suçla mücadele tekniklerini ve teknolojik imkânları kullanarak suç işleyen kişilerin, özellikle çok fazla suç işleyen kronik suçluların tamamını "kesin olarak" ve "en kısa sürede" (certainty and swift) yakalayarak toplumda tüm suçlular "muhakkak" yakalanır kanaatinin oluşmasını sağlamalıdırlar. Agnew bu önerisi ile polislik taktiklerinin suçu azaltmada etkili olduğunu kabul etmekte, sadece rehabilitasyona odaklanmamakta ve etkili polislik yöntemlerin uygulanmasını tavsiye etmektedir. İkinci olarak, polis ve diğer adalet çalışanları suçlulara karşı saygilı ve nazik olmalı ve özellikle yakalama anında kaba davranmamalıdırlar" (2005: 193). Agnew'in bu argümanını destekleyen sonuçlara ulaşan Johnson'a (2004) göre "vatandaşlar devlet ve adalet sistemi ile olan ilişkilerinde sonuca verdikleri önem kadar bu süreç içerisinde yetkililer tarafindan adil davranış görmeyi de önemsemektedirler" ve yetkililerin "tek taraflı, keyfi ve kaprisli davranışları vatandaşların adalet sistemine olan güvenini yok etmektedir" (Lambert, Hogan, Jiang, Elechi, Benjamin, Morris, Laux, \& Dupuy, 2010: 7).

Ayrıca, "tamir edici adalet" teorisinin argümanları takip edilerek mağdurlara verdikleri zararı anlamaları için ceza verme sürecine suçlular da dâhil edilmeli ve verilen cezayı benimsemeleri sağlanmalıdır. Bunlara ilaveten, topluma ciddi risk teşkil etmeyen bireyler cezaevine konmak yerine tedavi programlarına alınmalı ve sıkı bir şekilde takip edilmeliler ve cezaevlerinin suç ve gerilim üreten ortamına konulmamalıdırlar (Agnew, 2005:193-194). Bu görüşün doğruluğunu savunan MacKenzie ev hapsi ve elektronik izleme gibi yöntemlerin kullanılarak bazı suçluların cezaevlerine konmak yerine toplum içerisinde kontrol edilmeleri gerektiğini tavsiye etmektedir (1998).

Üçüncü olarak, cezaevinden çıkan kişiler sabıkalarından dolayı "toplum ve aileleri tarafindan kabul edilmemekte, iyi bir iş bulamamakta ve suçlu kişiler ile beraber olmaya mecbur bırakılmaktadırlar". Bu durum suçluların içine düştükleri "kısır döngüde sıkışıp kalmalarına ve tekrar suç işlemelerine" neden olmaktadır. Bu nedenle, "bu kişilerin iyi bir iş bulmaları sağlanılmalı, aileler ve toplumun diğer bireyleri affedici olmaları konusunda" teşvik edilmelidirler (Agnew, 2005: 195). Agnew'in bu önerilerini destekleyen Darcan yapmış olduğu çalışmasında özellikle cezaevinden çıkan kadınların topluma entegre olmakta ve asgari geçim masraflarını karşılamakta ciddi sorunlar yaşadıklarını belirtmektedir. Bu sorunların çözümü için hem genel olarak toplumun daha kucaklayıcı olması gerektiğini hem de görevlilerin, özellikle şartlı tahliye görevlilerinin yapıcı ve esnek olmaları gerektiğini tavsiye etmektedir (2014). Darcan'ın Amerika'daki mahkûmları inceleyerek Türkiye özelinde yapmış olduğu bu tavsiyeler Agnew'in teorisinin Türkiye'deki suçla mücadele politikalarında uygulanabilir olduğunun çok güzel bir örneğidir.

Son olarak, Agnew suçu azaltacak en önemli yöntemin suçun nedenlerini ortadan kaldırıc1 programların uygulanması olduğunu belirtmektedir. Bireyleri daha suç oluşmadan koruyacak ve suç işlemiş bireylerin tekrar suç işlemesini engelleyecek en önemli husus "suça neden olan faktörlerin uygulanacak koruyucu programlar ile daha oluşmadan tedavi edilmesini sağlamak, eğer oluştular ise hazırlanacak olan tedavi ve rehabilitasyon programlanı ile ortadan kaldırılmalarına çalışmak olacaktır. 
Eker, A. (2016). Agnew'in suç ve çocuk suçluluğu genel teorisinin temel unsurları, suç önleme politikalar1 ve limitleri. International Journal of Human Sciences, 13(1), 1945-1968. doi:10.14687/ijhs.v13i1.3735

Özellikle suça direkt etki eden beş yaşam alanını geliştirmek bu programların hedefi olmalıdır". Örneğin, "asabilik ve düşük öz-kontrol uygulanacak olan öfke kontrolü ve sosyal beceri kazandırıcı" programlar tarafindan rehabilite edilmeye çalışılmalıdır. Agnew "bu yaklaşımın diğer yaşam alanlarındaki sorunları gidermek için de kullanılması gerektiğini” belirtmektedir. Ancak bu noktada önemli bir uyarıda bulunmakta ve "beş yaşam alanının tüm olumsuzluklarına yullar boyunca ve kesintisiz olarak maruz kalan bireylerin olumsuz tavırlarının "bir konuşma veya broşür" ile değişmeyeceğinin bilinmesini" istemektedir. Bu olumsuzluklar ancak "aylarca hatta y1llarca sürecek olan ve etkili oldukları ispat edilmiş olan birçok yöntemin kullanılması" ile değiş̧ebilecektir. Bunlara ilaveten, "yüksek risk grubu bireylerin ve ailelerin taramalar sonucu tespit edilmesini ve koruyucu-tedavi edici programların erken dönemlerde başlaması" gerektiğini belirtmektedir. Son olarak, Agnew "bir veya daha fazla yaşam alanında çok ciddi sorunlar yaşayan kişilerin kronik suçlu olacaklarını ve çok fazla suç işleyeceklerini”" iddia etmektedir.Bu nedenle de "önemli miktardaki suçların önlenmesi için koruyucu ve tedavi edici programlar ile bu kişilerin problemlerinin öncelikli olarak giderilmesini" önermektedir (2005: 195-202).

\section{Eleştiriler}

Agnew genel suç teorisinde onlarca faktörü kullandığ için "bu teorisini tamamen test etmenin çok zor olduğunu çünkü tüm bu faktörleri içerecek verinin ve bilgisayar programlarının olmadığını" iddia etmektedir. Ancak, Zhang, Day, \& $\mathrm{CaO}^{4}$ lise öğrencilerinin dâhil olduğu 1,139 olay1, bu kişilerin beş yaşam alanlarına ait faktörleri ve diğer harici özelliklerini (yaş, cinsiyet, vb.) analiz etmiştir. Bu teorinin "temel argümanlarını destekleyecek sonuçlar bulsalar da yaşam alanlarındaki bazı faktörlerin suçluluğa önemli bir etkisinin olmadığı sonucuna ulaşmışlardır. Bireylerin yaşam alanlarında bulunan ve bu çalışmada analiz edilen 11 faktörden sadece beş tanesinin kayda değer etkisinin olduğunu" bulmuşlardır (2012: 857, 863 ve 874).

Türkiye'deki bir devlet üniversitesinde okuyan 974 öğrenciyi inceleyerek Agnew'in teorisini test eden Özbay Türkiye şartlarında yapılan analizinin bu toriye sadece kısmi destek bulduğunu belirtmektedir. Analiz etmiş olduğu 12 değişkenden sadece altı tanesinin istatistiki olarak etkili olduğunu bulmuştur (2011). Özbay 2014 yllında yayınlanan başka bir çalışmasında Agnew’in teorisinde ileri sürülen gerilim arttı̆ıında uyuşturucu kullanımı da artar savının Türkiye örnekleminde destklenmediğini ve gerilim yaşayan Türk öğrencilerin sadece çok az kısmının uyuşturucu kullanarak bu gerilimleri ile mücadele yöntemini seçtiklerini bulmuştur.

DeLisi cinayet gibi "şiddetli/ağır suçların toplumu suçtan korkuttuğunu, politikacıların ve adalet sisteminin suç hakkındaki görüşünü çok önemli oranda" şekillendirdiğini ancak Agnew'in teorisinin "gerilim ile şiddetli suçlar arasındaki bağlantıyı açıklayamadığını" belirtmektedir. Bunlara ilaveten, bu teorinin "cinsel suçlar gibi nöbetler halinde gelen (paroxysmal) şiddet suçlarını hangi faktörlerin tetiklediğini” açıklayamadığını ve nedensiz olarak işlenen (pathological) suçlara da odaklanmadığını iddia etmektedir. Ayrıca, bu teorinin tam anlamılla genel bir teori olabilmesi için "adalet sisteminin çalışmasını ve bu sistemin aktörlerinin her aşamadaki kararlarını nelerin şekillendirdiğini” de açıklaması gerektiğini belirtmiştir (2011: 1-2).

\section{Sonuç}

Özet olarak, Agnew bu teorisini şekillendirirken "biyolojik, psikolojik, sosyal kontrol, özkontrol, gerilim, sosyal öğrenme, sosyal destek ve damgalama" teorilerine ait olan ve birçok bilimsel araştırma tarafindan doğruluğu ispat edilen onlarca faktörü kullanmıştır (2005: 213). Agnew'e göre bu faktörler kişileri suça motive eden ve suçtan koruyan faktörleri şekillendirmektedir. Teorisinde bu faktörlere etki eden ve bireylerin davranışlarını, inanışlarını ve duygularını etkileyen ve şekillendiren beş yaşam alanının suça direk etti ettiğini, bu alanlarının birbirleri ile sürekli bir etkileşim halinde olduğunu, yaş ilerledikçe her bir alanın etkisinin değiştiğini ve özellikle önceki

\footnotetext{
${ }^{4} \mathrm{Bu}$ çalışma çok kapsamlı ve bilgilendirici olduğu için etkilişimi gösteren orijinal tablo bu makalenin sonunda EK-2
} olarak verilmiştir. 
Eker, A. (2016). Agnew'in suç ve çocuk suçluluğu genel teorisinin temel unsurları, suç önleme politikaları ve limitleri. International Journal of Human Sciences, 13(1), 1945-1968. doi:10.14687/ijhs.v13i1.3735

suçların ve olumsuz davranışların daha sonraki davranışlara çok önemli etkisinin olduğunu iddia etmektedir. Bu yaşam alanlarına ileve olarak biyolojik ve çevresel faktörlerin de kişilerin suç işlemesine dolaylı etkileri olduğunu iddia etmiştir (2005: 132).

Agnew'in bu teorisi genel olarak değerlendirildiğinde çok geniş ve kapsamlı olduğu, ancak bu genişliğine rağmen anlaşılmasının gerçekten kolay olduğu değerlendirilmektedir. Ancak birçok faktörü basit ve anlaşılması kolay bir şekilde organize etmesinin yanı sıra bu teorinin gerçekten çok tutarlı olduğu ve faktörlerin etkilerini değerlendirirken teoriyi güçlü göstermek için abartıll iddialarda bulunmadığ1 tespit edilmiştir. Buna en güzel örnek "olasıllk" tabirini tercih ederek "cebrilik" iddiasında bulunmamasıdır. Agnew bu yaklaşımı ile insan tabiatını, bireylerin davranış ve düşünce şeklini hangi faktörlerin ne oranda etkilediğini ve faktörlerin sınırlarını gerçekten kavradığını göstermektedir.

$\mathrm{Bu}$ teorinin en güçlü yönlerinden birisi de tüm faktörlerin karşllıklı etkileşim içerisinde olduğunu iddia etmesidir. Daha da önemlisi gelişimsel kriminolojinin hipotezlerini teorisine ekleyerek Şekil 3’te ayrıntılı olarak gösterildiği gibi bireylerin yaşlarının ilerlemesinin bazı faktörlerin etkisini azaltırken bazılarının etkisinin arttı̆ını belirtmesidir. Moffitt ve Laub gibi gelişimsel kriminolojiyi savunan araştırmacılar bu yaklaşımın suçu bütün yönleri ile kavramak ve etkili tedavi ve suç önleme metodları geliştirmek için şart olduğunu iddia etmektedirler. Agnew bu yaklaşımı teorisi ile bütünleştirerek gerçekten genel bir suç teorisi olmaya bir adım daha yaklaşmıştır.

$\mathrm{Bu}$ teorinin en suç teorileri literatürüne önemli katkısı bu makalenin ilk sayfalarında belirtildiği gibi aynı şartlara maruz kalan bireylerin bazıları suç işlerken diğer bireylerin neden suç işlemediğini açıklamaya çalışmasıdır. Agnew teorisini bu temel soruyu açılamak üzere düzenlemiştir çünkü bu tek soruya verilecek doğru ve kapsamlı cevaplar kriminoloji biliminin özünü oluşturmaktadır Agnew'e göre. Bu soruya cevap olmak üzere dizayn edilen bu teoriye göre yanıt aynı ortamda yaşayan bireylerin maruz kaldığı ve etkileşime geçtiği faktörlerin meydana çıkardığı olumlu ve olumsuz etkilerin güçlerindeki farklılıklardır. Hangi etki güçlü ise birey o etki doğrultusunda davranış sergileyecektir. Başka bir ifade ile olumlu etkiler fazla ise birey suçtan korunabilecektir. $\mathrm{Bu}$ sorunun cevabını açıklayan Agnew bireylerin suç ve diğer illegal aktivitelerini önleyebilmek için bireyi çevreleyen ve çok önemli oranda etkileyen beş yaşam alanının pozitif etkilerinin geliştirilmesi ve negatif etkilerinin giderilmesi gerektiğini önermektedir. Aslında bu yaklaşım tüm teorilerde bulunmaktadır. Örneğin, kontrol teorileri öz kontrolün geliştirilmesi gerektiğini belirtmektedir. Ancak bu teori bir faktöre odaklanmamakta ve fakat suça iten ve bireylerin suç işlemeye olan direncini artıran onlarca faktörü ve bu faktörlerin birbirleri ile olan etkileşimini anlatmaktadır.

Bu teorinin kriminoloji literatürüne, özellikle Türkçe suç litaratürüne olan en önemli katkısı birçok teoriyi analiz ederek geniş ve kapsamlı suç önleme tavsiyelerinde bulunmasıdır. Bu makalede de ayrıntılı olarak izah edildiği gibi kolluk güçlerine ve bireylerin iyileştirilmesi projelerinde görev alacak uzmanlara birçok teoriden aldığı tutarlı, karmaşık olmayan ve uygulanabilir tavsiyeler sunmaktadır. Özellikle tedavi programlarının yeterince uzun olması ve bir konuşma veya broşür ile insanların yıllar boyunca edindikleri kötü davranışlarının değişmeyeceğini belirtmesi çok önemlidir. İnsan davranışlarını değiştirmeye çalışanlar, özellikle cezaevlerindeki uzmanlar Agnew’in bu tavsiyesine uymalıdırlar.

Bunlara ilaveten yukarıda değinilen ve Türkiye'deki gençler üzerinde yapılan bilimsel çalışmalar Agnew'in daha önceki teorisinde ve bu teorisinde bulunan hipotezlerinin Türk gençliği için de geçerli olduğunu bulmuşlardır. Bu nedenle, Türkiyedeki suçluluğun ve özellikle çocuk suçluluğunun nedenleri üzerine araştırma yapan akademisyenler ve suç önleme politikaları geliştirecek olan kolluk kuvvetleri bu teoriden faydalanmalıdırlar.

Eleştiriler kısmında görüleceği üzere diğer teorilere nispeten yeni olan bu teori çok fazla test edilmemiş ve eksiklikleri açığa çıkartılmamıştır. Araştırmacılar bu teoriyi ve teoriyi oluşturan faktörleri test ederek güçlü ve zayıf yönlerini ortaya çıarmalıdır. Ancak Agnew'in de iddia ettiği gibi çok geniş olan bu teoriyi test etmek çok zor olacaktır. Bu nedenle çok kapsamlı çalışmalar yapılmalıdır. Özellikle Türk akademisyenler Türk örneklemler kullanarak ve bu örneklemleri birey seviyesinde uzun yıllar izleyerek bu teoriyi test etmeli ve suçun nedenlerini anlamaya çalışmalıdırlar. 
Eker, A. (2016). Agnew'in suç ve çocuk suçluluğu genel teorisinin temel unsurları, suç önleme politikaları ve limitleri. International Journal of Human Sciences, 13(1), 1945-1968. doi:10.14687/ijhs.v13i1.3735

Son olarak, Agnew'in bu teorisi yaklaşık on y1l önce yayınlanmış olsa da gerçekleştirilen Türkçe litaratür taramasında bu teorinin çok fazla kullanılmadığı ve test edilmediği, bu teoriden daha ziyade Agnew'in genel gerilim teorisinin dikkate alındığı tespit edilmiştir. Ayrıca, Türkiye'deki suç literatüründe yapılan taramada bazı çalışmaların suç teorilerini çok yüzeysel olarak özetlediği ve bir makale içerisinde 3-5 tane suç teorisinin özetlendiği tespit edilmiştir. Bu yaklaşımın doğru olmadığı ve suç teorilerini kapsamlı olarak anlatmaktan uzak olduğu değerlendirilmektedir. Orijinalinde yüzlerce sayfalık kitaplarda anlatılan suç teorilerini 1-2 sayfaya sığdırmak imkânsızdır. $\mathrm{Bu}$ yaklaşım teorilerin temellerini oluşturan faktörlerin etkilerini ve bu teoride ayrıntılı olarak anlatıldığı gibi faktörlerin karşılıklı etkileşmini suç teorilerini hiç bilmeyen birisine ayrıntılı olarak anlatmaktan çok uzak kalmaktadır. Bu nedenle, Agnew'in suç ve çocuk suçluluğunu tüm yönleri ile açılamak üzere geliştirdiği bu kapsamlı teori, bu teoride belirtilen iddialar ile ilgili bilimsel çalışmalarının sonuçları ve Agnew tarafindan yapılan suç önleme önerileri ayrıntıll olarak bu makalede anlatılmıştır. Bu yöntemin Türkiye'deki suç literatürüne, suç araştırmalarına, öğrencilerin suç teorilerini bütün yönleri ile kavramalarına ve kolluk kuvvetlerine katkı sağlayacağ1 değerlendirilmektedir.

\section{Yararlanılan Kaynaklar}

Agnew, R. (2005). Why Do Criminals Offend? A General Theory of Crime. Los Angeles: Roxbury Publishing.

Akers, R. L., (2003). A Social Learning Theory of Crime.Cullen, F. T. \& Agnew, R. (Ed.) içerisinde. Criminological Theory: Past to Present: Essential Readings. LosAngeles: Roxbury Publishing.

Anderson, E. (2003). The Code of the Streets. Cullen, F. T. \& Agnew, R. (Ed.) içerisinde. Criminological Theory: Past to Present: Essential Readings. LosAngeles: Roxbury Publishing.

Cohen, A. K. (2003). Delinquent Boys. Cullen, F. T. \& Agnew, R. (Ed.) içerisinde. Criminological Theory: Past to Present: Essential Readings. Los Angeles: Roxbury Publishing.

Cohen, L. E. \& Felson, M. (2003).Routine Activity Theory.Cullen., F. T. \& Agnew, R. (Ed.) içerisinde. Criminological Theory: Past to Present: Essential Readings. Los Angeles: Roxbury Publishing.

Darcan, E. (2014). Kadın mahkûmların cezaevinden çıktıktan sonra toplumsal hayata katılmada Yaşadıkları zorluklar. Sosyal Politika Calıșalar Dergisi, Vol 32: 87-111.

DeLisi, M. (2011). How general is general strain theory? Journal of Criminal Justice. Vol:39

Farrington, D. P. (2003). "Developmental and life-course criminology: Key theoretical and empirical issues- The 2002 Sutherland award address", Criminology, V.41, No.2, pp.221-256.

Froggio, G. (2007) Strain and Juvenile Delinquency: A Critical Review of Agnew's General Strain Theory, Journal of Loss and Trauma: International Perspectives on Stress \& Coping, 12: 4, 383-418,

Glueck, S \& Glueck, E. (2003).Unraveling juvenile delinquency. Cullen, F. T. \& Agnew, R. (Ed.) içerisinde. Criminological Theory: Past to Present: Essential Readings. LosAngeles: Roxbury Publishing.

Hay, C. (2003). Family strain, gender, and delinquency.Sociological Perspectives, 46, $107-135$.

Hirschi, T. (2003).Social Bond Theory. Cullen, F. T. \& Agnew, R. (Ed.) içerisinde. Criminological Theory: Past to Present: Essential Readings. LosAngeles: Roxbury Publishing.

Hollist, D. R., Hughes, L. A., \& Schaible, L. M. (2009). Adolescent maltreatment, negative emotion, and delinquency: An assessment of general strain theory and family based strain. Journal of Criminal Justice, 37, 379-387.

Ibabe, I. \& Jaureguizar, J. (2010). Child-to-parent violence: Profile of abusive adolescents and their families. Journal of Criminal Justice, 38, 616-624. 
Eker, A. (2016). Agnew'in suç ve çocuk suçluluğu genel teorisinin temel unsurları, suç önleme politikaları ve limitleri. International Journal of Human Sciences, 13(1), 1945-1968. doi:10.14687/ijhs.v13i1.3735

Lambert, E. G., Hogan, N. L., Jiang, S., Elechi, O. O., Benjamin, B., Morris, A., Laux, J. M., \& Dupuy, P. (2010). The relationship between distributive and procedural justice and correctional life satisfaction, burnout, and turnover intent: An exploratory study. Journal of Criminal Justice, 38, 7-16.

MacKenzie, D. (1998). Criminal Justice and Crime Prevention.InPreventing Crime: What Works, What Doesn't, What's Promising. Washington DC: U.S. Department of Justice, National Institute of Justice. Retrieved from https://www.ncjrs.gov/works/chapter9.htm

Matsueda, R. L. (2001). Labeling Theory: Historical Roots, Implications, and Recent Developments.Paternoster, R. \& Bachman, R. (Ed.) içerisinde. Explaining Criminals and Crime: Essays in Contemporary Criminological Theory. LosAngeles: Roxbury Publishing.

Merton, R. K. (2003). Social Structure and Anomie. Cullen, F. T. \& Agnew, R. (Ed.) içerisinde. Criminological Theory: Past to Present: Essential Readings. LosAngeles: Roxbury Publishing.

Moffitt, Terrie E., (1993), “Adolescent-limitedand life-course-persistentantisocialbehavior: A developmentaltaxonomy". Psychological Review. Vol:100, pp.674-701.

Moon, B., Hays, K., \& Blurton, D. (2009).General strain theory, key strains, and deviance.Journal of Criminal Justice, 37, 98-106.

Özbay, Ö. (2011). Does general strain theory account for youth deviance in Turkey? Nevşehir Üniversitesi Sosyal Bilimler Enstitüsü Dergisi Vol. 1: 107-129.

Özbay, Ö. (2014). General Strain Theory And Substance Use. Turkish Journal of Police Studies, Vol. 16: 1 .

Sampson, Robert J. \& Laub, John H., (2003).Crime and the Life Course.Cullen, F. T. \& Agnew, R. (Ed.) içerisinde. Criminological Theory: Past to Present: Essential Readings. LosAngeles: Roxbury Publishing.

Sankır, H. (2014). Gençlerin sapmış ve suçlu davranışlara yönelmelerinde benlik saygısının etkisi: Lise 11. sınıf örneği. Turkish Studies - International Periodical For The Languages, Literature and History of Turkish or Turkic Vol.9 No. 2: 1311-1333.

Schroeder, R. D., Hill, T. D., Haynes, S. H., \& Bradley, C. (2011). Physical health and crime among low-income urban women: An application of general strain theory. Journal of Criminal Justice.Vol. 39: 21-29.

Sutherland, E. H. \& Cressey, D. R. (2003). A Theory of Differential Association. Cullen, F. T. \& Agnew, R. (Ed.) içerisinde. Criminological Theory: Past to Present: Essential Readings. LosAngeles: Roxbury Publishing.

Stogner, J.,\& Gibson, C. L. (2010). Healthy, wealthy, and wise: Incorporating health issues as a source of strain in Agnew's general strain theory. Journal of Criminal Justice, 38, 1150-1159.

Sullivan, C. J. (2006). Early Adolescent Delinquency: Assessing the Role of Childhood Problems, Family Environment, and Peer Pressure. Youth Violence and Juvenile Justice, Vol. 4 No. 4, October: 291-313.

Swatt, M. L., Gibson, C. L., \& Piquero, N. L. (2007).Exploring the utility of general strain theory in explaining problematic alcohol consumption by police officers.Journal of Criminal Justice, 35, 596-611.

Vold, G. B., Bernard, T. J., \& Snipes, J. B. (2002).Theoretical Criminology.New York: Oxford University Press.

Wolfgang, M., E. \& Ferracuti, F. (2003).The Thesis of a Subculture of Violence. Cullen, F. T. \& Agnew, R. (Ed.) içerisinde. Criminological Theory: Past to Present: Essential Readings. Los Angeles: Roxbury Publishing.

Zhang, Y., Day, G. \& Cao, L. (2012).A Partial Test of Agnew's General Theory of Crime and Delinquency.Crime \& Delinquency. Vol: 58: 856 
Eker, A. (2016). Agnew'in suç ve çocuk suçluluğu genel teorisinin temel unsurları, suç önleme politikaları ve limitleri. International Journal of Human Sciences, 13(1), 1945-1968. doi:10.14687/ijhs.v13i1.3735

\section{Ek-1}

\section{Extended English Abstract}

Based on his 25 years' experience, Agnew developed this General Theory of Crime and Delinquency to answer the question "why do criminal offend?" Moreover, he tried to explain the underlying reasons of offending and tried to answer "why are some individuals more likely than others to engage in crime?" According to Agnew, these two questions are the core questions that general public concern about, and criminologists' obligation should be finding satisfactory and accurate answers to them.

In order to provide comprehensive answers to above fundamental questions, Agnew has integrated and re-organized several leading criminological theories and results of empirical researches arguing that this new general theory has the capability of explaining all crime types. While composing this theory, Agnew neither lists all factors that have been found influential on offending by leading theories, nor does he focus on only one factor and analyze it deeply. Rather, he re-grouped the variables that cause crime. Fundamentally, Agnew argues that lifespan of an individual is covered by five life domains: self, family, peer, school and work. These life domains affect and shape individuals' behaviors and decision making process throughout his or her life cycle starting from the early childhood.

Self (super personality traits of irritability and low self-control) implies that if an individual has irritability and low sel-control traits he/she will be "impulsive, poor in social and problem-solving skills", will have "focusing problems, low emphaty to others' feeelings, and will engage in exiting, risky, and illegal behaviors" more frequently. Family refers to negative parenting, absence of positive parenting and bonding, poor supervision and discipline, family conflict, and criminal parents/siblings". Peer life domain suggests that if an individual has "criminal peers and spent more time with them during unsupervised activities", their chance of offending will increase. School refers to "negative bonding to teachers and school, poor academic performance, little time spent on homework, negative treatment by teachers, and poor discipline at school". Work life domain implies that "unemployment, negative bonding to work, poor working contitions, and criminal co-worker" affect offending. Agnew claims that if the varibales encompassed by these five life domains provide positive support, the probability of offending will decrease. However, if they produce negative effects, the chance of commiting crime will be very high. Agnew claims that effect level of each domain will vary as individuals get older. For example, effect of family domain will decrease when a child starts to go to school while effects of peers and school will increase.

In addition, several external factors (biological and environmental factors) have effects on individuals. In order to commit crimes, these external factors should interact with each other and with five life domains. Biological factors are shaped by "genetic and nongenetic" factors. Genetic factors are "inherited" from biological parents, such as low IQ. Nongenetic biological factors refer to "biological harms caused by bad habits of mother during pregrancy (poor nutrition, alcohol and drug use), and delivery complications, such as brain damage". For example, Agnew claims that "low serotonin negatively affects nervous system and functions of brain, and lower one's inhibitions". Environmental factors imply that "low sosyoeconomic status of parents, individuals' age, gender, race, characteristics of the community in which they live" have huge effect on "parenting skills, stress level of parents, crime exposure of the juveniles, and presence of negative role models".

According to this general theory, these life domains, biological and environmental factors not only affect individuals but also have mutual effect on each other. Agnew claims that each variable has effect on other variables and is affected by others at the same time. For example, poor parenting has negative effect on traits of children, such as low self-control and lack of 
Eker, A. (2016). Agnew'in suç ve çocuk suçluluğu genel teorisinin temel unsurları, suç önleme politikaları ve limitleri. International Journal of Human Sciences, 13(1), 1945-1968. doi:10.14687/ijhs.v13i1.3735

discipline, poor school performance, and chance of having criminal peers. Poor school performance effet future work quality, sosyoeconomic status, and marriage endurance. Agnew argues that negative effects of all these variables evolve "a web of crime", and "escaping from this web will be very difficult after trapping in it".

Moreover, it is claimed in theory that one of the strongest factors that predict future offending is prior crimes because prior crimes motivate offenders if those crimes are not detected. If they are detected and offenders are convicted, they will be labeled as criminals and lose legal oppurtunities to meet their needs. Thus, they will be pushed into crime in either circumstance.

It is claimed in this theory that five life domains and other factors mutually affect "constraint against crime and motivation for crime". Agnew claims that these constraints and motivations explain the reasons "why some individuals are more likely than others to engage in crime". He argues that if effects of variables on "constraint against crime" are more powerful than effects on "motivation for crime", inidividuals will be restrained from offending. But, if motivation for crime is higher as a result of negative effects of variables, the chance of offending will be high.

In order to reduce crime, Agnew purposes several suggestions. Firstly, "police should use recent technological developments" and effective tactics to increase certainity and swiftness. This will increase general deterrence via affecting perception of people. Secondly, Agnew claims that fairness and politeness of all criminal justice actors will eliminate the negative effects of sanctions and punishmets, and reduce the anger level of offenders. Later, society members, especially families and close friends of offenders should not reject individuals when they offend. These people should be convinced by authorities via educational programs to accept criminals. Finally, variables that cause crime should be eliminated at early stages via educational and rehabilitation programs. These programs should be long enough to change long-lasting behaviors of individuals.

Although Agnew claims that this theory is difficult to test, some researchers tested it and found that not all variables listed in this theory have effect on crime. Researchers found that only five of eleven tested variables have been founded having significant effect on criminal behavior. Moreover, it is claimed that this theory is lack of explanatory power on "paroxysmal and pathological" crimes, such as murder and rape.

Finally, this paper tries to explain the core elements of this comprehensive theory. All variables listed within five life domains, biological and environmental factors are mentioned in detail. Their effects on individuals' behaviors and decision-making process, and interactions among these variables have been presented. Researches conducted in Turkey are included to review the generalizability of the theory. Moreover, crime prevention suggestions of Agnew and limitation of the theory is mentioned. 
Eker, A. (2016). Agnew'in suç ve çocuk suçluluğu genel teorisinin temel unsurları, suç önleme politikaları ve limitleri. International Journal of Human Sciences, 13(1), 1945-1968. doi:10.14687/ijhs.v13i1.3735

\section{Ek-2}

Tablo 1: 15-18 yaş aralığında işlenen şiddet suçlarını erken ve geç dönemlerde etkileyen faktörler

\begin{tabular}{|c|c|c|c|}
\hline \multirow[t]{2}{*}{ Alan } & \multicolumn{2}{|c|}{ Risk Faktörleri } & \multirow[t]{2}{*}{ Koruyucu Faktörler } \\
\hline & Erken Başlama (6-11) & Geç Başlama (12-24) & \\
\hline \multirow{13}{*}{ Bireysel } & Genel Suçlar & Genel Suçlar & $\begin{array}{l}\text { Sapkınlığa karşı toleranssız } \\
\text { yaklaşım }\end{array}$ \\
\hline & Madde kullanımı & Psikolojik Durum & \\
\hline & Erkek olmak & Tezcanlılık & Yüksek IQ \\
\hline & Agresiflik $^{\pi}$ & Konsentre eksikliğî́ & Kadın olmak \\
\hline & Psikolojik durum & Risk alma & $\begin{array}{l}\text { Olumlu sosyal oryantasyon } \\
\text { Kanunların çiğnenmesi karşısında } \\
\text { algısal müeyyide }\end{array}$ \\
\hline & Hiperaktivite & Agresiflik $^{*}$ & \\
\hline & \multirow{2}{*}{$\begin{array}{l}\text { Problem (Antisosyal) } \\
\text { davranış }\end{array}$} & Erkek olmak & \\
\hline & & Fiziksel şiddet & \\
\hline & \multirow[t]{2}{*}{ TV şiddetine maruz kalma } & $\begin{array}{l}\text { Antisosyal tutum ve } \\
\text { inanıș }\end{array}$ & \\
\hline & & Kișilere karşı suç & \\
\hline & $\begin{array}{l}\text { Sağlık ve fiziksel problemler } \\
\text { Düşük IQ }\end{array}$ & $\begin{array}{l}\text { Problem (Antisosyal) } \\
\text { davranış }\end{array}$ & \\
\hline & Antisosyal tutum ve inanç & Düşük IQ & \\
\hline & Yalancılık ${ }^{*} *$ & Madde kullanımı & \\
\hline \multirow{10}{*}{ Aile } & \multirow[b]{2}{*}{$\begin{array}{l}\text { Düşük sosyoekonomik } \\
\text { durum }\end{array}$} & Zayıf aile-çocuk ilişkisi & $\begin{array}{l}\text { Ebeveynler ve diğer yetişkinlerle } \\
\text { ılımlı, sıcak ve destekleyen bir ilişki }\end{array}$ \\
\hline & & $\begin{array}{l}\text { Sert, gevşek veya } \\
\text { istikrarsız disiplin: } \\
\text { yetersiz gözetleme }\end{array}$ & \\
\hline & \multicolumn{2}{|l|}{ Antisosyal ebeveyn } & \\
\hline & \multirow[t]{2}{*}{ Zayıf aile-çocuk iliş̧kisi } & $\begin{array}{l}\text { Düşük aile ilgisi- } \\
\text { katılımı }\end{array}$ & $\begin{array}{l}\text { Ebeveynlerin çocuğun arkadaşlarını } \\
\text { onaylaması }\end{array}$ \\
\hline & & Antisosyal ebeveyn & \\
\hline & $\begin{array}{l}\text { Sert, gevşek veya istikrarsız } \\
\text { disiplin }\end{array}$ & $\begin{array}{l}\text { Parçalanmış aile } \\
\text { Düşük sosyoekonomik }\end{array}$ & Ebeveyn izlemesi \\
\hline & Parçalanmışaile & durum/fakirlik & \\
\hline & Ebeveynlerden ayrılık & $\begin{array}{l}\text { Sui muamele eden } \\
\text { ebeveyn }\end{array}$ & \\
\hline & Diğer durumlar & Diğer durumlar & \\
\hline & $\begin{array}{l}\text { Sui muamele eden ebeveyn } \\
\text { Illgisiz ebeveyn }\end{array}$ & Aile içi çatışma* * & \\
\hline \multirow[t]{2}{*}{ Okul } & \multirow[t]{2}{*}{$\begin{array}{l}\text { Zayıf sosyal tutumlar ve } \\
\text { performans }\end{array}$} & $\begin{array}{l}\text { Zayıf tutumlar ve } \\
\text { performans }\end{array}$ & Okula karşı olumlu tutumlar \\
\hline & & Akademik başarısızlık & Geleneksel aktivitelere katılım \\
\hline \multirow[t]{3}{*}{ Arkadaşlar } & \multirow{3}{*}{$\begin{array}{l}\text { Zayıf sosyal bağlar } \\
\text { Anti sosyal arkadaşlar }\end{array}$} & Zayıf sosyal bağlar & $\begin{array}{l}\text { Uyumlu davranışlara sahip } \\
\text { arkadaşlar }\end{array}$ \\
\hline & & $\begin{array}{l}\text { Anti sosyal ve suçlu } \\
\text { arkadaşlar }\end{array}$ & \\
\hline & & Çete mensubiyeti & \\
\hline \multirow[t]{2}{*}{ Toplum * } & & $\begin{array}{l}\text { Sokak suçları, } \\
\text { uyuşturucu }\end{array}$ & \\
\hline & & Mahallenin düzensizliği & \\
\hline
\end{tabular}

Kaynak: Youth Violence: A Report of the Surgeon General (2001) (Chapter 4). 
Eker, A. (2016). Agnew'in suç ve çocuk suçluluğu genel teorisinin temel unsurları, suç önleme politikaları ve limitleri. International Journal of Human Sciences, 13(1), 1945-1968. doi:10.14687/ijhs.v13i1.3735

\section{Ek-3}

Şekil 4: Zhang ve Arkadaşların Yapmış Olduğu Kapsamlı Analiz Sonucu

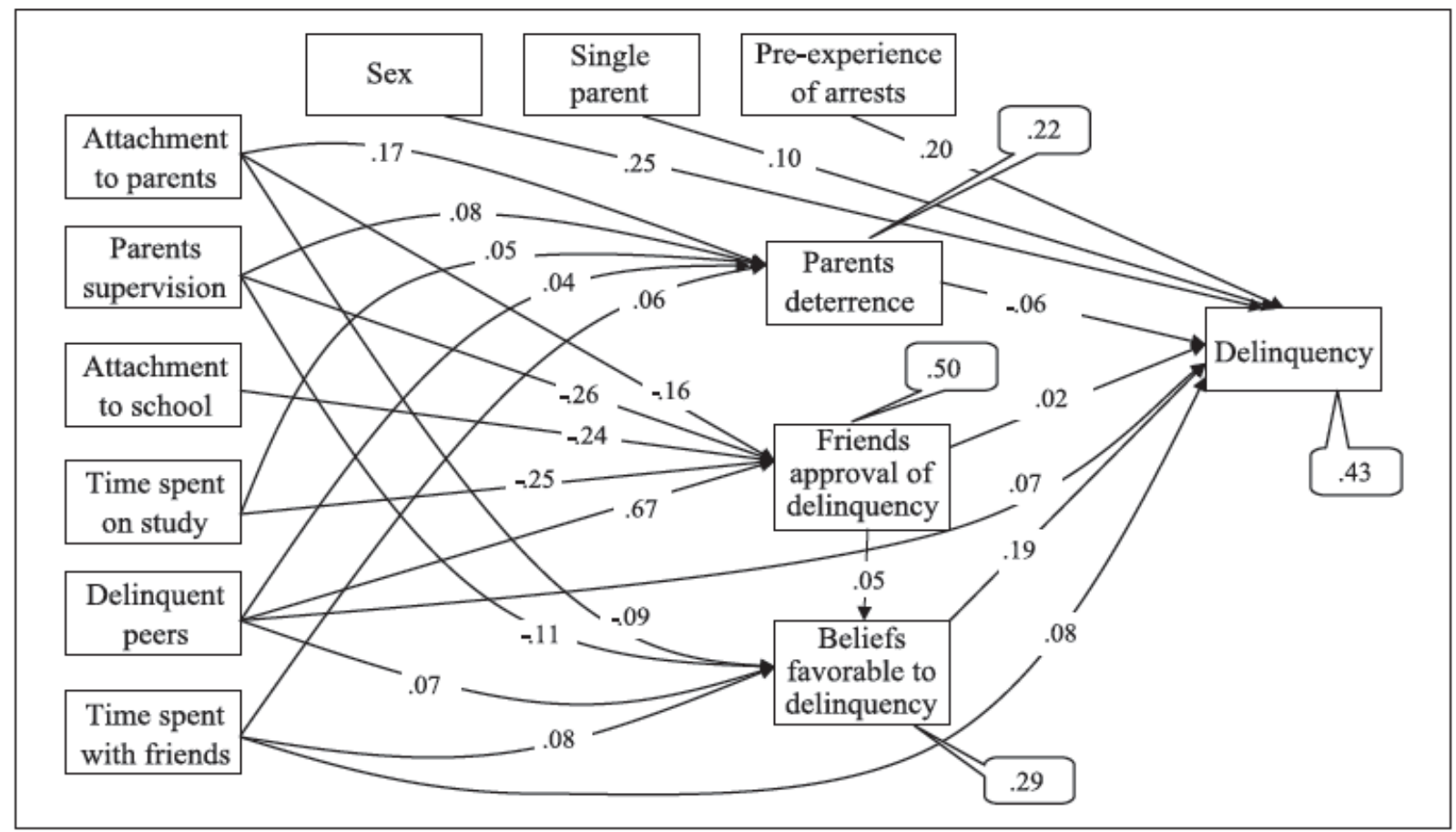

Figure I. Path analysis of the relationship between life domains, constraints, motivations, and delinquency

Note:All the coefficients are significant at the .05 level. The number in the box indicates the $R^{2}$. $\chi^{2}(19)=48$, root mean square error of approximation $=.037$, comparative fit index $=.994$, goodness-of-fit index $=.994$, adjusted goodness-of-fit index $=.969$.

Kaynak: Zhang ve arkadaşları. (2012: 872). 